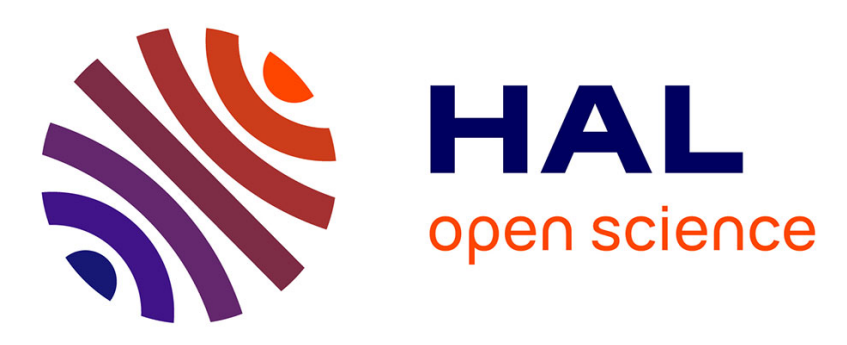

\title{
Chemical and structural stability of La0.6Sr0.4Co0.2Fe0.8O3 $-\delta$ ceramic vs. medium/high water vapor pressure
}

Settakorn Upasen, Pierre Batocchi, Fabrice Mauvy, Aneta Slodczyk, Philippe Colomban

\section{To cite this version:}

Settakorn Upasen, Pierre Batocchi, Fabrice Mauvy, Aneta Slodczyk, Philippe Colomban. Chemical and structural stability of La0.6Sr0.4Co0.2Fe0.8O3- $\delta$ ceramic vs. medium/high water vapor pressure. Ceramics International, 2015, 41 (10, Part B), pp.14137-14147. 10.1016/j.ceramint.2015.07.035 . hal01187643

\section{HAL Id: hal-01187643 \\ https: / hal.sorbonne-universite.fr/hal-01187643}

Submitted on 27 Aug 2015

HAL is a multi-disciplinary open access archive for the deposit and dissemination of scientific research documents, whether they are published or not. The documents may come from teaching and research institutions in France or abroad, or from public or private research centers.
L'archive ouverte pluridisciplinaire HAL, est destinée au dépôt et à la diffusion de documents scientifiques de niveau recherche, publiés ou non, émanant des établissements d'enseignement et de recherche français ou étrangers, des laboratoires publics ou privés. 


\title{
Chemical and structural stability of $\mathrm{La}_{0.6} \mathrm{Sr}_{0.4} \mathrm{Co}_{0.2} \mathrm{Fe}_{0.8} \mathrm{O}_{3-\delta}$ ceramic vs. medium/high water vapor pressure
}

Settakorn Upasenª, Pierre Batocchic, Fabrice Mauvyc, Aneta Slodczyk ${ }^{\mathrm{a}, \mathrm{b}}$, Philippe Colomban ${ }^{\mathrm{a}, \mathrm{b}^{*}}$

a Sorbonne Universités, UPMC Univ Paris 06, UMR 8233, MONARIS, 75005, Paris, France

b CNRS, UMR 8233, MONARIS, F-75005, Paris, France

c ICMCB, ICMCB-CNRS-IUT-Université de Bordeaux, 33608 PESSAC Cedex, France

*corresponding author at :

Tel+33144272785; fax +33144273021

E-mail address: philippe.colomban@upmc.fr

\begin{abstract}
:
During the last decades, perovskite-type oxides have received large attention as potential electrolytes and electrodes for Solid Oxide Fuel Cells (SOFC), including Proton Ceramic Fuel Cells (PCFC), gas separation membranes and High Temperature Steam Electrolysers (HTSE). A thermal treatment in autoclave, at a temperature close to an operating temperature, was used to measure the chemical stability of $\mathrm{La}_{0.6} \mathrm{Sr}_{0.4} \mathrm{Co}_{0.2} \mathrm{Fe}_{0.8} \mathrm{O}_{3-\delta}$ (LSCF6428) ceramic under medium and high water pressure ( $20 \& 40$ bar). This mixed ionic-electronic conductor (MIEC) exhibits interesting properties as cathode of fuel cell materials. The reactivity rate of the investigated LSCF6428 sample under the protonation process conditions (several weeks at $550^{\circ} \mathrm{C}$ using $\mathrm{CO}_{2}$-free and $\mathrm{CO}_{2}$-saturated water) was studied in order to evaluate a potential use of this compound. Bulk and surface tructural/chemical changes were characterized by optical microscopy, TGA, dilatometry,
\end{abstract}


Raman and ATR-FTIR spectroscopy. The results revealed only minor surface modifications in the case of ceramic treated under medium vapor pressure (20 bar) using $\mathrm{CO}_{2}$-free water. On the contrary, under higher pressure (40 bar) and $\mathrm{CO}_{2}$-saturated water several second phases were detected, namely strontianite, cobalt oxides and hematite. The chemical/structural stability of LSCF6428 is compared with previously investigated RareEarth nickelate ceramics: $\mathrm{La}_{2} \mathrm{NiO}_{4+\delta} / \mathrm{Pr}_{2} \mathrm{NiO}_{4+\delta} / \mathrm{Nd}_{2} \mathrm{NiO}_{4+\delta}$.

Keywords: B: Spectroscopy; Surface; C: Corrosion; Lifetime; D: perovskite; E: Fuel cell 


\section{Introduction}

Solid Oxide Fuel Cells (SOFC) received a large attention because of their high efficiency and low pollution emissions [1]. The oxygen ion conducting SOFCs based on zirconia/ceria electrolyte operate at high temperature, typically above $800^{\circ} \mathrm{C}$. Such a high working temperature reduces the material's lifetime and increases significantly operating costs. To overcome these drawbacks, recent studies have paid attention to proton conducting electrode/electrolyte materials able to operate at lower temperatures (500$700^{\circ} \mathrm{C}$ ) [2-5]. Such lower operating temperatures allow the use of less expensive steels and keeping of low-cost catalyzers. Reversibly, the electrochemical cells can be adapted to be used in High Temperature Steam Electrolyzer (HTSE). One great advantage of proton conductors for HTSE is the production of dry pure hydrogen in the cathode side. Electrode materials should exhibit important mixed ionic and electronic conductivity (MIEC) as well as show high efficiency and high stability vs. protons and/or oxygen/hydrogen. Furthermore, they should be also stable vs. other gas components such as $\mathrm{CO}_{2}, \mathrm{NO}_{\mathrm{x}}$ which could reduce the stability and the efficiency of the MIEC-materials as well as accelerate its ageing through chemical/structural transitions [6-8].

Different perovskite-related oxides exhibiting a large range of properties regarding to the variety of structure and chemical compositions have been tested as electrodes successfully [9]. Among various electrodes, $\mathrm{La}_{0.6} \mathrm{Sr}_{0.4} \mathrm{Co}_{0.2} \mathrm{Fe}_{0.8} \mathrm{O}_{3-\delta}$ (LSCF6428) exhibits excellent ionic-electronic conducting properties over a wide temperature range [10]: for example at $900^{\circ} \mathrm{C}$ the electronic conductivity can reach $230{\mathrm{~S} . \mathrm{cm}^{-1}}^{-1}$ whereas oxygen \left. conductivity is $0.2{\mathrm{~S} . \mathrm{cm}^{-1}}^{-11}, 12\right]$. Proton conductivity is expected but not yet 
demonstrated. Only few results are reported in the literature concerning electrochemical characterizations of similar MIEC-materials as a function of $\mathrm{p}\left(\mathrm{H}_{2} \mathrm{O}\right)[3,13,14]$. At room temperature, LSCF shows almost cubic structure, with a small orthorhombic or rhombohedral distortion in the case of low Co and Sr contents. At high temperatures and/or high Sr content, a cubic phase is observed [15-17]. Structural stability of LSCF7382 was analyzed under $\mathrm{H}_{2}$ atmosphere in a wide temperature range; reversible transition from the perovskite $\mathrm{ABO}_{3}$ phase to the brownmillerite $\mathrm{A}_{2} \mathrm{~B}_{2} \mathrm{O}_{5}$ was detected at $250-300^{\circ} \mathrm{C}$. Moreover, decomposition of the structure into $\mathrm{Co}, \mathrm{La}_{2} \mathrm{O}_{3}, \mathrm{SrO}$ and $\mathrm{LaSrFeO}_{4}$ was observed above $750^{\circ} \mathrm{C}$ $[18,19]$.

In our previous studies, we demonstrated the potential of high pressure/middle temperature autoclave to study the chemical stability of various perovskite-type electrolytes and electrodes vs. high pressurized water $[20,21]$. Such treatment $\left(550-600^{\circ} \mathrm{C}\right.$, 10-40 bar $\left.\mathrm{p}\left(\mathrm{H}_{2} \mathrm{O}\right)\right)$ that allows also incorporation of protonic species into a host material structure is called "Protonation". Note, the use of medium pressure allows also to optimize the economic efficiency of Fuel Cells and Electrolysers. Operating conditions (typically 10 to 20 bar $\mathrm{p}\left(\mathrm{H}_{2} \mathrm{O}\right)$ ) [IND] are the must. The use of high water pressure by industrialists allows an increased efficiency and in consequence decreasing of Hydrogen production/conversion cost [22-27]. Our previous studies, performed in a strict collaboration with Industrial partner, showed however that high water pressure can significantly accelerate a material ageing [membrane]. Consequently, our protonation procedure performed under very high pressure (40 bar $\mathrm{p}\left(\mathrm{H}_{2} \mathrm{O}\right)$ ) can be considered as an accelerated stability test which allows very fast to choose the most stable $[22,23]$. 
The protonation process leads to subtle modifications of a material structure whatever the small amount of incorporated protons [28-35]. The quantity of $\mathrm{CO}_{2}$ dissolved in the water used is one of the stringent parameters. With high water pressure, the water activity at the ceramic surface increases, and enhances many reactions (hydroxylation, carbonation, or protonation). Consequently, a significant amount of secondary phases can be formed in relatively small experimental time (days to weeks). Careful analysis of the secondary phases with usual analytical techniques permits the study of the corrosion mechanism. Following the procedure of the previous studies, the LSCF6428 ceramic sample was treated under medium/high water vapor pressure $(\sim 20$ and $\sim 40$ bar $)$ at $550^{\circ} \mathrm{C}$ for several days using a home-designed autoclave device [20, 28-32]. Two kinds of water were used: i) $\mathrm{CO}_{2}$-free water ii) $\mathrm{CO}_{2}$-saturated water. Thermogravimetry (TGA), thermal expansion (TE), X-ray diffraction (XRD), Attenuated Transmitted Reflected Fourier Transform-infrared spectroscopy (ATR FT-IR), Raman Spectroscopy (RS) were employed in order to identify corrosion films as well as eventual structural changes associated to the proton/water insertion. The aim of this study is the comprehension of the reaction mechanisms in operating proton conductor-based device conditions. Structural/chemical modifications allowing to estimate ageing of LSCF6428 ceramic were compared with other alternative cathode materials, namely Ln-nickelates [21].

\section{Materials and Methods}

Sample preparation: $A$ ceramic of $\mathrm{La}_{0.6} \mathrm{Sr}_{0.4} \mathrm{Co}_{0.2} \mathrm{Fe}_{0.8} \mathrm{O}_{3-\delta}$ (LSCF6428) composition, called hereafter 'as-prepared' sample, was prepared in pellet form $(\varnothing=\sim 16 \mathrm{~mm}$, thickness $=1.48$ mm, theoretical density of $95 \%$ max.). The preparation method was described by Mauvy and Batocchi [3]. Commercial powders provided by Marion Technology (Verniolle, France) 
were isostatically pressed into pellets at 3000 bar for 5 minutes and then sintered in air at $1350^{\circ} \mathrm{C}$ for 4 hours. The thermal treatment of some as-prepared sample was carried out from $40^{\circ} \mathrm{C}$ to $1000^{\circ} \mathrm{C}$ using a TG balance (heating rate $=10^{\circ} \mathrm{C} / \mathrm{min}, 3$ cycles) under $\mathrm{He}$ atmosphere.(99.99\%, $\mathrm{H}_{2} \mathrm{O}<3$ ppm vol., $\mathrm{O}_{2}<2$ ppm vol., $\mathrm{C}_{\mathrm{n}} \mathrm{H}_{\mathrm{m}}<0.5$ ppm vol., Alphagaz-1, Air Liquide, France).

Autoclave treatment: The as-prepared ceramic was treated under high/medium water vapor pressure $\left(20 / 40 \mathrm{bar}, 550^{\circ} \mathrm{C}, \mathrm{CO}_{2}\right.$-free and $\mathrm{CO}_{2}$-saturated water) for period of 8 to 47 days using the home designed autoclave device [20, 28-32]. This device is equipped with a temperature and pressure controller, which allows us to follow the protonation process/incorporation of water/protonic species from the pressure drop. Note, Figure S1 (Supplementary Material) illustrates temperature and pressure curves recorded during the protonation process. The curves consist of two regions - start-up and protonation. The pressure drop in the protonation region was adjusted to 30 bar by the mean of a small leak valve. The further pressure decreases with a time is related to the absorption of water by the ceramic. The sample weight was systematically analyzed by non-destructive techniques after each run of autoclave treatment in order to observe the kinetic of protonation/reactions.

Optical microscope analysis: Micro-structures were analyzed on the surface as well as on a fresh fracture section of protonated samples using an Optical Microscope Olympus BX51 instrument. The 50x and 100x objectives were selected in order to observe microstructure modifications in the 5-1000 $\mu \mathrm{m}$ range. Grains and pores sizes were measured using a lineintercept method (ASTM E112) with high magnification $(10 \mu \mathrm{m})$ of the micro-feature. Image contrast was optimized using the Microsoft Office Picture software. 
Thermal analysis: TGA was performed between $40^{\circ} \mathrm{C}$ and $1000^{\circ} \mathrm{C}$ using a Setaram Setsys Evolution thermobalance. The use of Pt-crucible and He- atmosphere $\left(99.99 \%, \mathrm{H}_{2} \mathrm{O}<3\right.$ ppm vol., $\mathrm{O}_{2}<2$ ppm vol., $\mathrm{C}_{\mathrm{n}} \mathrm{H}_{\mathrm{m}}<0.5 \mathrm{ppm}$ vol., Alphagaz-1, Air Liquide, France) allows the significant enhancement of the measurement accuracy. Thermal expansion (TE) measurements were carried out between $40^{\circ} \mathrm{C}$ and $600^{\circ} \mathrm{C}$ under Ar- atmosphere (99.99\%, $\mathrm{H}_{2} \mathrm{O}<0.5$ ppm vol., $\mathrm{O}_{2}<0.1$ ppm vol., $\mathrm{CO}<0.1$ ppm vol., $\mathrm{CO}_{2}<0.1$ ppm vol., $\mathrm{H}_{2}<0.1$ ppm vol., $\mathrm{C}_{\mathrm{n}} \mathrm{H}_{\mathrm{m}}<0.5 \mathrm{ppm}$ vol. Alphagaz-2, Air Liquide, France) using a Setaram Setsys 1650 dilatometer instrument equipped with amorphous silica rod and support.

Vibrational spectroscopy analysis: Raman spectra were recorded at room temperature under $458 \mathrm{~nm}$ and $514 \mathrm{~nm}$ wavelengths using a HR800 spectrometer (Horiba, John Yvon) equipped with a Peltier effect cooled CCD detector. The measurements under $785 \mathrm{~nm}$ wavelength were also performed using the solid state source line of a Senterra spectrometer (Bruker Optics, Karlsruhe, Germany). Raman spectra were recorded between $50 \mathrm{~cm}^{-1}$ and $4000 \mathrm{~cm}^{-1}$ through the $50 \mathrm{x}$ long working distance objectives (N.A. $=0.50$ ). It was previously pointed out that moderate power of illumination may significantly heat the black ceramic samples [21,36]. Consequently, in order to select the convenient laser power and to avoid phase transformation, preliminarily power tests were performed by varying the output power from 0.1 to $20 \mathrm{~mW}$. Correct signal/noise ratios were obtained with relatively high counting duration of 100-500s. The spectra were fitted using Origin Software. The Raman mapping, furthermore, was performed on fresh fracture section of the protonated samples. The spectra were recorded from fresh surface deep to the sample's core with interval line of a few microns $(5-50 \mu \mathrm{m})$. 
ATR FT-IR spectra were recorded between $600 \mathrm{~cm}^{-1}$ and $4000 \mathrm{~cm}^{-1}$ at room temperature using the Bruker IR-scope FTIR spectrometer in ATR modes: a Diamond ATR $\left(2 \times 2 \mathrm{~mm}^{2}\right)$ and a Germanium micro ATR $\left(20 \times 20 \mu \mathrm{m}^{2}\right)$ crystal.

X-ray Diffraction: XRD patterns of ground pellets were collected on a PANalitycal X'pert MPD-PRO Bragg-Brentano of $\theta-2 \theta$ geometry diffractometer equipped with a germanium primary monochromator over an angular range of $2 \theta=10-130^{\circ}$. Each acquisition lasted for 64 hours. The $\mathrm{Cu}-\mathrm{K} \alpha_{1}(\lambda=1.54056 \AA)$ radiation was generated at $45 \mathrm{kV}$ and $40 \mathrm{~mA}$. Unitcell parameters were calculated by Le Bail profile matching. The phase identification was carried out using the ICCD database and PANatycal X'pert highscore software. The relative quantities of the different phases were estimated according to the ratio of the relative intensities of the major peaks recorded in the XRD patterns.

\section{Results and Discussion}

\subsection{Characterization of the pristine LSCF ceramic}

\subsubsection{Mean symmetry}

The XRD results presented in Fig.1 show that LSCF6428 exhibits a single rhombohedral phase with $R$-3c space group. The pristine symmetry of the material investigated here is then similar to previous literature studies $[3,37,38]$. Structural modifications involved by the autoclave treatment will be discussed in section 3.3.

\subsubsection{Raman scattering}

Because of the black color of the as-prepared LSCF6428 sample that leads to high conversion of the laser beam to heat at the examined spot, Raman spectra shown in Fig. 2a 
were recorded as a function of laser power $\left(0.1-20 \mathrm{~mW}, 458 \mathrm{~nm}, 135-1250 \mathrm{~cm}^{-1}\right)$. At the lowest power $(\sim 0.15 \mathrm{~mW})$, the spectrum reveals the presence of typical LSCF perovskite phase consisting of a main peak at $662 \mathrm{~cm}^{-1}$ and three broad bands at 569, 470, and $292 \mathrm{~cm}^{-}$ 1. A small broad band at $180 \mathrm{~cm}^{-1}$ is also detected. The first two bands at 662 and $569 \mathrm{~cm}^{-1}$ are similar to those observed in the literature [18, 39-42]. It should be noted that according to its complex composition, LSCF6428 can be considered as a solid solution between La ${ }_{\mathrm{x}} \mathrm{Sr}_{\mathrm{x}} \mathrm{CoO}_{3-\delta}$ (LSC) and $\mathrm{La}_{1-\mathrm{x}} \mathrm{Sr}_{\mathrm{x}} \mathrm{FeO}_{3-\delta}$ (LSF). The large bandwidth is related to the $\mathrm{Co} / \mathrm{Fe}$ and La/Sr partial substitutions. The group theory analysis in the case of rhombohedral symmetry with the $R$-3c space groups predicts 18 optical phonons of irreducible representations [40]. Fives modes $\left(A_{1 g}+4 E_{g}\right)$ are Raman actives, and eight modes $\left(3 A_{2 u}+5 E_{u}\right)$ are IR actives, while the remaining modes $\left(2 A_{1 u}+3 A_{2 g}\right)$ are inactive. According to the literature [39], the Raman bands at 650 and $590 \mathrm{~cm}^{-1}$, typical of the LSCF material, correspond to $E_{g}$ modes.

With increase of the laser power, the temperature at the sample surface increases, which can lead to oxidation reaction. Simultaneously a wavenumber downshift is expected and observed under $2.5 \mathrm{~mW}$ laser beam. According to the study of Siebert et al. [18], the Raman spectrum of fully oxidized LSCF7382 exhibits an overlapping of two broad bands centered at 560 and $630 \mathrm{~cm}^{-1}$. Our spectra showing bands at 569 and $662 \mathrm{~cm}^{-1}$, Fig. 2a, are consistent with a low oxygen deficiency. Overall area of spectrum and relative intensity between the band at 569 and $662 \mathrm{~cm}^{-1}$, plotted as a function of the output laser power, are shown in Fig. 2b. The result shows a decrease of the sum of peak area with the increase of the laser power. This vanishing of Raman signature is consistent with the progressive transition toward the cubic structure [20,43]. Moreover, a jump of the relative intensity 
$\left(\mathrm{I}_{569} / \mathrm{I}_{662}\right)$ at $2.5 \mathrm{~mW}$ of laser power was clearly observed and indicates a phase transition due to local heating under the laser beam. Consequently, only the Raman spectra recorded below this limit power of $2.5 \mathrm{~mW}$, can be considered as showing the "true" signature of the pristine LSCF6428 ceramic at room temperature, as analyzed by XRD (Fig. 1).

Raman spectra, Fig. 3, were recorded under different laser lines: $458 \mathrm{~nm}, 514 \mathrm{~nm}$ and $785 \mathrm{~nm}$ with 50x objectives in several surface spots. The $458 \mathrm{~nm}$ spectrum under 0.15 $\mathrm{mW}$ laser power shows the signatures of a pure LSCF perovskite phase as discussed earlier. A rather similar spectrum is obtained under $3 \mathrm{~mW}$ with $785 \mathrm{~nm}$ exciting line indicating a lower light absorption - and heating - in near IR range. Additional narrow Raman peaks at about 685,518 , and $480 \mathrm{~cm}^{-1}$ were observed. These peaks can be assigned to the contribution of $\mathrm{Co}_{3} \mathrm{O}_{4}$ second phase. A reference spectrum given in Fig. 3 has been obtained by heating of $\mathrm{CoO} . \mathrm{OH}$ heterogenite [44]. The small wavenumber shift and relative intensity change arise from the (pre)resonance Raman effect [45]. No "well-defined" spectrum of CoO phase seems to be available in the literature. Very low intense spectrum with broad bands at 465 and $675 \mathrm{~cm}^{-1}$ is given by Tang et al. [46]. According to Tang et al.' assignment, the CoO contribution in the Raman spectrum is detected by the broadening of the $461 \mathrm{~cm}^{-1}$ peak. Alternatively, the Raman spectrum of CoO.OH (Fig. 3) shows a narrow peak at $498 \mathrm{~cm}^{-}$ 1 and a broad feature at $\sim 620 \mathrm{~cm}^{-1}$ that may explain the rather high intensity of the $\sim 480$ $\mathrm{cm}^{-1}$ peak. Anyway, the intense light absorption of the black material promotes the transformation of (hydroxylated) $\mathrm{CoO}$ into $\mathrm{Co}_{3} \mathrm{O}_{4}$ under the laser beam. The observation of a band at $\sim 1140 \mathrm{~cm}^{-1}$ is also consistent with hydroxylated $\mathrm{CoO}$ [44]. Traces of metal transition oxides are commonly observed in similar compounds [46]. 


\subsection{Protonation treatment under medium/high pressure}

\subsubsection{Reactivity vs. water}

The investigated LSCF6428 ceramic was treated, similarly to our previously investigated nickelate-based samples [21,36], using an autoclave device under $\sim 20$ bar of $\mathrm{CO}_{2}$-free water pressure at $550^{\circ} \mathrm{C}$. The mass variation between pristine and protonated ceramics was recorded versus time. Consequently, the mass difference per sample surface area $\left(\mathrm{mg} / \mathrm{mm}^{2}\right)$ exposed to water pressure was calculated using equation 1 . The graph of the calculated mass change vs. protonation time is plotted in semi-logarithmic scale as shown in Fig. 4.

$$
\text { Mass uptake }\left(m g / m^{2}\right)=\frac{m_{i}-m_{0}}{S}, \quad \quad \mathrm{i}=1,2,3, \ldots
$$

where $m_{0}$ is the as-prepared sample weight $(\mathrm{mg}), \mathrm{m}_{\mathrm{i}}$ is the sample weight of $\mathrm{i}=1,2,3 \ldots$ protonation runs up to the complete studied time range and $S$ is sample surface area, $2 \pi r^{2}+h(2 \pi r)$

The exponential fitting curves, Fig. 4, reveal very low corrosion of the LSCF6428 ceramic in comparison with our previously investigated nickelates $[21,36]$. The reactivity rate of the LSCF6428 sample is about 1:42, 1:22 and 1:8 of the reactivity rate in the case of LNO, PNO and NNO sample, respectively. Hence, the LSCF6428 ceramic exhibits the highest stability under 20 bar of $\mathrm{CO}_{2}$-free water pressure at $550^{\circ} \mathrm{C}$.

\subsubsection{Microstructures}

The samples were categorized in different states; as-prepared/pristine (a), as-prepared sample thermally treated at $1000^{\circ} \mathrm{C}\left(\mathrm{a}^{\prime}\right)$, protonated (b, c, d), and deprotonated by thermal 
treatment at $1000^{\circ} \mathrm{C}\left(b^{\prime}, c^{\prime}, d^{\prime}\right)$. Figure 5 illustrates the surface microstructure features of each sample states. The surface of as-prepared sample (Fig. 5a) as well as that of the thermally treated sample (Fig. 5a') show grains of $\sim 1-2 \mu \mathrm{m}$ with pores of $\sim 2$ to $10 \mu \mathrm{m}$. A white contour is observed at the grain periphery and assigned to $2^{\text {nd }}$ phase traces already identified by XRD and Raman analysis. In the case of the ceramic protonated under 40 bar of $\mathrm{CO}_{2}$-free water for a short period of 8 days (Fig. 5b), the observed surface habits are similar to those detected for the as-prepared sample. However, we observe an increase of the number of grains affected by the white contour. This may indicate an increase of the secondary phase content. In the case of thermally treated protonated LSCF6428 using $\mathrm{CO}_{2}$ free water (Fig. 5b' and 5c'), the surface habit remains rather similar to that of the asprepared and thermally treated as-prepared samples, in agreement with good stability of the ceramic.

In the case of the ceramic protonated under $\mathrm{CO}_{2}$-saturated water, the surface features were more affected - small aggregates $(\sim 4 \mu \mathrm{m})$ were covered by another phase. After deprotonation performed at $1000^{\circ} \mathrm{C}$ (Fig. $5 \mathrm{c}^{\prime}$ ), the microstructure remains rather stable. By comparison with previously analysed protonated nickelate homologues $[21,36]$, no crack was observed neither for the protonated nor the deprotonated LSCF6428 ceramics, treated either under $\mathrm{CO}_{2}$-free or $\mathrm{CO}_{2}$ saturated water.

\subsection{Chemical and structural modifications}

\subsubsection{Thermogravimetry and thermal expansion}

Fig. 6a compares the TGA curves of non-protonated and protonated LSCF6428 ceramic. According to the oxygen mobility $[11,15,16]$, the weight loss observed above $600^{\circ} \mathrm{C}(\mathrm{He}$ 
atmosphere) in the case of non-protonated pellets can be related to the equilibration of the oxygen stoichiometry with the new environment, different from the sintering atmosphere [47]. The variation is very weak according previous measurement of the oxygen stoichiometry [2]. Furthermore the low delta value limits the number of vacancies. In order to highlight the contribution solely due to the autoclave treatment, the oxygen stoichiometry variation was suppressed by subtracting the measure made on the nonprotonated, as-prepared sample: the relative mass-loss difference between non-protonated and protonated samples is plotted in Fig. 6b. The difference curve clearly shows the presence of one weak peak at $\sim 400^{\circ} \mathrm{C}$ in the case of medium-pressure $(\sim 20$ bar $)$ protonated samples. For the high-pressure (40 bar) protonation, a second stronger peak is observed at $\sim 800^{\circ} \mathrm{C}$. According to previous studies $[20,28,29]$, the phenomenon at $300-400^{\circ} \mathrm{C}$ can be assigned to the decomposition of hydroxide(s), and that at $\sim 800-900^{\circ} \mathrm{C}$ to the carbonate decomposition.

According to the above TG data and hypothesis that the ceramic exhibits a single phase and that the initial $\delta$ oxygen stoichiometry is not modified at $550^{\circ} \mathrm{C}$ in the autoclave, the following formula can be proposed for protonated LSCF6428 ceramic under 40 bar of $\mathrm{CO}_{2}$ absorped water pressure: $\mathrm{La}_{0.4} \mathrm{Sr}_{0.6} \mathrm{Fe}_{0.2} \mathrm{Co}_{0.8} \mathrm{O}_{3-\delta}(\mathrm{OH})_{0.01 \cdot}\left(\mathrm{CO}_{3}\right)_{0.04}$. In the case of ceramics treated under free- $\mathrm{CO}_{2}$ water pressure in both medium and high pressure, the content of hydroxides moieties was much lower $\left(<0.001\right.$ mole/mole $\left.\mathrm{pH}_{2} \mathrm{O}\right)$.

Comparison of thermal expansion (TE) curves characteristic of non-protonated and protonated LSCF6428 samples is presented in Fig. 6c. The area located in-between heating and cooling curves of pristine, non-protonated sample is rather small, revealing stability of the material (measured temperature range is far below the sintering temperature of the 
ceramic pellet). Only the first heating TE curve of protonated pellet ( $\sim 40$ bar of $\mathrm{CO}_{2}$-free vapor pressure) shows clearly a contraction jump at $\sim 350^{\circ} \mathrm{C}$. A similar phenomenon was observed in our previous works devoted to stability studies of nickelate-based oxides [21, 36]. Furthermore, a study on phase transition of LSCF7382 under $\mathrm{H}_{2}$ atmosphere by Siebert et al. [18], points out the transformation from rhombohedral perovskite structure to orthorhombic $\mathrm{A}_{2} \mathrm{~B}_{2} \mathrm{O}_{5}$ brownmillerite phase at $350^{\circ} \mathrm{C}$. Formation of a hydroxide film at the ceramic surface could also explain the presence of such a jump since dehydration of hydroxides is observed in this temperature range. The lack of cracks in the ceramic pellet is more consistent with the assignment of this jump modification to the presence of $2^{\text {nd }}$ phase surface film than to the effect of the phase transition involving a contraction of the unit-cell in the bulk.

\subsubsection{Unit-cell symmetry}

Figures 1a and 1b compare XRD patterns of as-prepared and 20 bar protonated/ 40 bar protonated using $\mathrm{CO}_{2}$-free water LSCF6428, respectively. Extra Bragg peaks observed after protonation treatment confirm the presence of cobalt oxide(s), namely CoO. According to the refinement of XRD patterns and relative ratio analysis, the amount of cobalt oxide(s) traces can be estimated to $1-2 \%$ depending on the protonation pressure - the higher pressure value, the higher percentage of $\mathrm{CoO}$. The detection of $\mathrm{Co}_{3} \mathrm{O}_{4}$ by Raman spectroscopy could be due to the presence of both $\mathrm{CoO}$ and $\mathrm{Co}_{3} \mathrm{O}_{4}$. Note, the higher Raman intensity of $\mathrm{Co}_{3} \mathrm{O}_{4}$ hinders the observation of $\mathrm{CoO}$ signature and/or the oxidation of $\mathrm{CoO}$ can appear under the laser beam heating. Taking into account the unit-cell parameters and space group given in Table 1, it is clear that the protonated LSCF6428 keeps the rhombohedral symmetry, no matter the protonation pressure value is. The protonation 
treatment under medium and high pressure causes a small expansion of unit-cell volume: $0.57 \%$ for 20 bar protonation and $1.10 \%$ for 40 bar protonation. This volume expansion could be consistent with the contraction observed in Fig. 6c, because of the departure of protons inserted in the perovskite structure.

Table 1: XRD analyses of as-prepared and protonated LSCF6428 samples.

\begin{tabular}{|c|c|c|c|c|c|c|c|}
\hline \multirow{2}{*}{ Sample } & \multirow{2}{*}{$\begin{array}{c}\text { phase } \\
\text { symmetry of } \\
\text { perovskite } \\
\text { structure }\end{array}$} & \multirow{2}{*}{$\begin{array}{l}\text { Space } \\
\text { group }\end{array}$} & \multicolumn{3}{|c|}{ Unit-cell parameters } & \multirow{2}{*}{$\mathbf{V}\left(\AA^{3}\right)$} & \multirow{2}{*}{$\begin{array}{l}\Delta \mathrm{V} \\
(\%)\end{array}$} \\
\hline & & & $\mathbf{a}(\AA)$ & $\mathbf{b}(\AA)$ & $\mathbf{c}(\AA)$ & & \\
\hline LSCF6428 & rhombohedral & $R-3 c$ & $5.4878(5)$ & $5.4878(5)$ & 13.374(4) & $348.8(1)$ & - \\
\hline LSCF6428. $H^{+}$ & rhombohedral & $R-3 c$ & $5.4936(8)$ & $5.4936(8)$ & 13.423(8) & $350.8(2)$ & +0.57 \\
\hline (20 bar $\mathrm{CO}_{2}$-free water) & $+\mathrm{CoO}$ & & & & & & \\
\hline LSCF6428.H+ & rhombohedral & $R-3 c$ & $5.5107(1)$ & $5.5107(1)$ & 13.4088(3) & 352.64(1) & +1.10 \\
\hline (40 bar $\mathrm{CO}_{2}$-free water) & $+\mathrm{CoO}$ & & & & & & \\
\hline
\end{tabular}

\subsubsection{Vibrational spectroscopy analysis}

Raman spectra recorded at the surface of protonated LSCF6428 samples, Fig. 7a, clearly reveal the presence of secondary phases i.e. oxide(s), hydroxide(s) and carbonate(s) depending on protonated/thermal treatment conditions.

i) In the case of protonation performed under 20 bar using $\mathrm{CO}_{2}$ free- water $(20$ bar, P20), Raman signatures at 688, 611, 493, 407, 289, and $221 \mathrm{~cm}^{-1}$ were observed. These Raman peaks are assigned to hematite, $\alpha-\mathrm{Fe}_{2} \mathrm{O}_{3}[48]$.

ii) For higher pressure of $\mathrm{CO}_{2}$ free-water (40 bar, $\mathrm{P} 40$ ), the Raman spectrum shows traces of lanthanum oxycarbonate $\left(\mathrm{La}_{2} \mathrm{O}_{2} \mathrm{CO}_{3}\right)$. Our reference spectra of $\mathrm{LaOOH} .\left(\mathrm{CO}_{3}\right)$ and 
$\mathrm{La}(\mathrm{OH})_{3}$ obtained by in-situ thermal treatment of hydroscopic $\mathrm{La}_{2} \mathrm{O}_{3}$ powder are given in Fig. S2 (Supplementary Material). The Raman signature detected at $1066 \mathrm{~cm}^{-1}$ is assigned to internal stretching mode $\left(\mathrm{A}_{1 \mathrm{~g}}\right)$ of $\mathrm{C}-\mathrm{O}$ bonds [49].

iii) For the ceramic treated under 40 bar of $\mathrm{CO}_{2}$-saturated water pressure (40 bar, $\mathrm{P} 40 / \mathrm{CO}_{2}$ ), Raman spectra recorded at the surface show carbonate signature: the peaks at $1073,702,247,182$, and $150 \mathrm{~cm}^{-1}$ were assigned to strontium carbonate, $\mathrm{SrCO}_{3}$, with its characteristic $1073 \mathrm{~cm}^{-1}$ symmetric stretching mode $\left(v_{1}\right)$ of $\mathrm{C}-0$ bond [50]. A peak at $\sim 865$ $\mathrm{cm}^{-1}$ and a weak band at $\sim 567 \mathrm{~cm}^{-1}$ can be assigned to a strontium oxide/peroxide. This result is similar to that presented in the study of Waal [51], where a peak at $863 \mathrm{~cm}^{-1}$ is attributed to the $\mathrm{O}-\mathrm{O}$ stretching mode of $\mathrm{SrO}_{2}$ composition, and three very weak bands at $563,537,522 \mathrm{~cm}^{-1}$ are assigned to translation modes of Sr-O vibrational unit. The presence of Sr-based oxides could be related to the thermal decomposition of the Sr-carbonate under the laser spot because of a black matrice.

Table 2: Raman wavenumbers of the different second phases found on the bulk and surface of protonated LSCF6428 ceramics.

\begin{tabular}{|c|c|c|c|}
\hline Phase & Symbol* & wavenumber $\left(\mathrm{cm}^{-1}\right)^{+}$ & References \\
\hline $\mathrm{SrO}$ & $\phi$ & $\underline{560}, 540,520$ & {$[51]$} \\
\hline $\mathrm{SrO}_{2}$ & $\Delta$ & $\underline{863}$ & \\
\hline $\mathrm{Co}_{3} \mathrm{O}_{4}$ & $\sigma$ & $\underline{686}, \underline{614}, \underline{520}, \underline{479}, \underline{191}$ & {$[44,52-54]$} \\
\hline$\gamma-\mathrm{Fe}_{2} \mathrm{O}_{3}$ & $\gamma$ & $\underline{700}, \underline{600}, \underline{495}, \underline{406}, \underline{292}, 247, \underline{226}$ & {$[48]$} \\
\hline $\mathrm{LaO} . \mathrm{OH}$ & $\mu$ & $\begin{array}{c}424, \underline{383}, \underline{345}, 312,216,202,165,135,123 \text {, } \\
116\end{array}$ & [49] \\
\hline $\mathrm{SrCO}_{3}$ & $*$ & $1446, \underline{1071}, \underline{710}, 511,258, \underline{245}, 237, \underline{180}$, & {$[50,55]$} \\
\hline
\end{tabular}




\begin{tabular}{lcc}
\hline & $\underline{148}, 100$ \\
${\mathrm{I}-\mathrm{La}_{2} \mathrm{O}_{2} \mathrm{CO}_{3}}^{* *}$ & $\underline{1064}, \underline{868}, 721,670,315$ & [49] \\
\hline *: symbols used in Fig. 7 & \\
+: underline Raman wavenumbers are observed in this study
\end{tabular}

Figure 7b shows representative Raman spectra recorded in the bulk of LSFC6428 ceramic treated under different protonation conditions. Measurements are made on the fresh fracture of the ceramic pellet, from surface to the bulk centre.

i) Raman spectra characteristic of the sample treated under 20 bar $/ \mathrm{CO}_{2}$-free (at 510 $\mu \mathrm{m}$ bulk) and $40 \mathrm{bar} / \mathrm{CO}_{2}$-saturateded water (at $50 \mu \mathrm{m}$ bulk), reveal the presence of traces of Cobalt spinel $\left(\mathrm{Co}_{3} \mathrm{O}_{4}: 689,618,523,485\right.$, and $\left.195 \mathrm{~cm}^{-1}\right)$. However, some slight peak downshifts are detected between pure $\mathrm{Co}_{3} \mathrm{O}_{4}$ and that present in protonated LSCF6428.

ii) Raman spectrum recorded on bulk, $50 \mu \mathrm{m}$ depth (protonated under 20bar, Fig. $7 \mathrm{~b})$, shows the bands at $606,501,404,288$ and $221 \mathrm{~cm}^{-1}$ which are characteristic of hematite $\left(\alpha-\mathrm{Fe}_{2} \mathrm{O}_{3}\right)[56]$.

ATR-FTIR technique specially probes the surface, typically a few (tenths) micron indepth penetration: the exact penetration depth varies with the wavenumber depending on the optical index of the crystal probe (diamond or germanium, Fig. 8). Depending on the band intensity and optical characteristic of the investigated solid (the higher optical index , the higher reflection), the band shape is complex and can be described as a mixture of absorption and reflection signal $[57,58]$. Thus, it is not possible to discus the crystallinity of the second phases. The ATR-FTIR tests were performed on the as-prepared (a, b), protonated in different conditions (c, d, and e) and thermally treated as-prepared (f) 
samples. A sharp peak observed at $\sim 3604 \mathrm{~cm}^{-1}$ can be assigned to the stretching mode of $\mathrm{OH}^{-}$in $\mathrm{Sr}(\mathrm{OH})_{2}$. This contribution confirms the presence of protonic species absorbed on the ceramic surface. The absorption bands at $600-1500 \mathrm{~cm}^{-1}$ detected in the case of protonated samples correspond to traces of $\mathrm{SrCO}_{3}$ [30]. The strong absorption peak centered at 1422 $\mathrm{cm}^{-1}$ and the band at $701 \mathrm{~cm}^{-1}$ are assigned to the asymmetric stretching $\left(\mathrm{v}_{3}\right)$ and bending (U4) vibrations of C-O bonds, respectively. A strong narrow peak at $\sim 859 \mathrm{~cm}^{-1}$ can be assigned to the out-of-the-plane bending $\left(\mathrm{v}_{2}\right)$ mode, and that observed at $\sim 1071 \mathrm{~cm}^{-1}$ to the fully symmetric stretching $\left(\mathrm{v}_{1}\right)$ mode of $\mathrm{CO}_{3}^{2-}$ ions. The absorption bands characteristic of $\operatorname{Sr}(\mathrm{OH})_{2}$, and $\mathrm{SrCO}_{3}$ observed here are similar to those presented in the literature $[59,60]$.

\subsection{LSCF6428 chemical stability}

A Raman mapping was performed on the cross-section of a fresh fractured sample from the top surface (directly exposed to the vapor pressure) down to the bottom one (in contact with the autoclave chamber) in step of few micron to $50 \mu \mathrm{m}$. This procedure is the so-called Raman profilometry method discussed in details in our previous studies [20, 21, 35, 36]. Figure 9 compares the Raman mapping spectra recorded for ceramics protonated using three distinct conditions: 20 bar of free- $\mathrm{CO}_{2}$ water pressure (47 days), 40 bar of free$\mathrm{CO}_{2}$ water pressure (8 days) and 40 bar of $\mathrm{CO}_{2}$-saturated water pressure (8 days). The relative volume section of phase modification is summarized in Table 3.

Table 3: comparison of corrosion in LSCF6428 dense ceramic.

Section (\%)

Protonation conditions 


\begin{tabular}{cccc}
\hline & $\begin{array}{c}\text { 20 bar/47days free- } \\
\mathrm{CO}_{2} \text { water }\end{array}$ & fo bar/8days & 40 bar/8days \\
& $<0.1$ & $\sim 0.4$ & saturated-CO $\mathrm{CO}_{2}$ water \\
\hline Top layer & 99.9 & 99.2 & $\sim 0.7$ \\
core & $<0.1$ & $\sim 0.4$ & 98.9 \\
Bottom layer & & & $\sim 0.4$ \\
\hline
\end{tabular}

Due to the possibility of focusing at the microscale on a sample surface, the Raman technique has higher ability than the usual XRD technique to detect even small structural changes as well as secondary phases. However, the combination of the black color of the matrix/substrate and the laser spot can lead to uncontrolled heating and then structural/chemical transformations (partial dehydration/oxidation) under the laser light as discussed in section 3.12. The dehydration of those hydrated/hydroxylated substrate derivatives may induce phase transitions/transformations and hence a higher number of phases that explains the higher number of phases detected by vibrational spectroscopy. Furthermore, the vibrational spectroscopy techniques are able to reveal the presence of amorphous oxyhydroxides, not detectable by XRD [20,30]. Since the Raman intensity depends on the chemical bond polarisability, minor phases may have a stronger signature than the major matrix.

No transformation on the top layer of protonated LSCF6428 is observed after protonation under 20 bar. Traces of hematite $\left(\alpha-\mathrm{Fe}_{2} \mathrm{O}_{3}\right)$ and cobalt oxide are observed in some spots in the bulk due to defects formed in the powder processing and/or sintering. On the contrary, the Raman spectra characteristic of the ceramics protonated under 40 bar of both $\mathrm{CO}_{2}$-free and -saturated water, show the presence of carbonate compounds (nearly 
surface, $<1 \mu \mathrm{m}$ ) as well as other hydroxide(s)/oxide(s) phases. The carbonate phases are identified as strontianite $\left(\mathrm{SrCO}_{3}\right)$ and lanthanum oxycarbonate $\left(\mathrm{I}-\mathrm{La}_{2} \mathrm{O}_{2} \mathrm{CO}_{3}\right)$. Hydroxide(s)/oxide(s) phase are identified as lanthanide oxyhydroxide (LaO.OH) and cobalt oxides $\left(\mathrm{Co}_{3} \mathrm{O}_{4}\right)$. Note, comparison of $2^{\text {nd }}$ phase volumes between medium and high vapor pressure protonation treatments indicates that they are not significantly different.

\section{Conclusions}

According to the protonation treatment $\left(\sim 20\right.$ and $\sim 40$ bar of $\mathrm{CO}_{2}$-free or $\mathrm{CO}_{2}$-saturated water, $550^{\circ} \mathrm{C}$ ) and several advanced analysis techniques, we can summarize that the LSCF6428 ceramic exhibits very good stability under medium and high water pressure, 5 to 30 times better than nickelates homologues (Table S1). XRD results show that the structure of protonated pellets remains rhombohedral $(R-3 \mathrm{c})$ with a small unit-cell expansion related to proton incorporation. Only traces of secondary phases were detected in the ceramic bulk. XRD reveals the formation of $\mathrm{CoO} . \mathrm{Fe}_{2} \mathrm{O}_{3}$ traces are also observed within the bulk as processing defects. Raman spectroscopy shows the presence of oxyhydroxide(s). According to TG results, the content of $\mathrm{OH}^{-}\left(<0.01\right.$ mole $/$ mole. $\left.\mathrm{H}_{2} \mathrm{O}\right)$ is very low. Raman mapping allows an identification of surface corrosion products: the hematite $\left(\alpha-\mathrm{Fe}_{2} \mathrm{O}_{3}\right)$, cobalt oxides $\left(\mathrm{CoO} / \mathrm{Co}_{3} \mathrm{O}_{4}\right)$, tetragonal lanthanum oxycarbonate $\left(\mathrm{I}-\mathrm{La}_{2} \mathrm{O}_{2} \mathrm{CO}_{3}\right)$, and strontianite $\left(\mathrm{SrCO}_{3}\right)$. The type and content of these secondary phases depend on the protonation conditions (i.e. $\mathrm{CO}_{2}$ contents, pressure, duration times). As expected, the highest content of carbonates is found after the treatment using $\mathrm{CO}_{2}$-saturated water.

Fig. 10 compares the rate of the formation of the corrosion film thickness formed at the surface of 'dense' ceramic pellets used as electrolytes (BCZ:YZ, $B a C e_{0.5} Z_{0.3} Y_{0.16} Z_{0.04} O_{3-\delta}$ ' 
$\left.B Z: Y b, B a Z r_{0.9} Y b_{0.1} O_{3-\delta ;} S Z: Y b, S r Z r_{0.9} Y b_{0.1} O_{3-\delta}\right)[20]$ and electrodes $\left(\mathrm{Ln}_{2} \mathrm{NiO}_{4+\delta} L n=L a, L a N O\right.$, $L n=\operatorname{Pr}, \operatorname{PrNO}$ and $L n=N d, N d N O ; L S C F 6428$ ) [21]. Under medium water pressure the stability of electrode materials and of strontium zirconate electrolyte is good. Under high water pressure barium-base perovskite electrolytes are no more stable and if the water has been saturated with $\mathrm{CO}_{2}$ the superior stability of LSCF compound is demonstrated whatever the lower carbonation of Pr and Nd-based compounds vs. La, Ba or even Sr homologues. 


\section{References}

[1] A.B. Stambouli, E. Traversa, Solid oxide fuel cells (SOFCs): a review of an environmentally clean and efficient source of energy, Renewable and Sustainable Energy Reviews 6 (2002) 433-455.

[2] A. Grimaud, F. Mauvy, J.M. Bassat, S. Fourcade, L. Rocheron, M. Marrony, J.C. Grenier, Hydration Properties and Rate Determining Steps of the Oxygen Reduction Reaction of Perovskite-Related Oxides as H+-SOFC Cathodes, J Electrochem. Soc. 159 (2012) B683-B694

[3] B. Philippeau, F. Mauvy, C. Mazataud, S. Fourcade, J.-C. Grenier, Comparative study of electrochemical properties of mixed conducting $\mathrm{Ln}_{2} \mathrm{NiO}_{4+d}(\mathrm{Ln}=\mathrm{La}, \mathrm{Pr}, \mathrm{Nd})$ and $\mathrm{La}_{0.6} \mathrm{Sr}_{0.4} \mathrm{Co}_{0.2} \mathrm{Fe}_{0.8} \mathrm{O}_{3-\mathrm{d}}$ as SOFC cathodes associated to $\mathrm{Ce}_{0.9} \mathrm{Gd}_{0.1} \mathrm{O}_{2-\mathrm{d}}, \mathrm{La}_{0.8} \mathrm{Sr}_{0.2} \mathrm{Ga}_{0.8} \mathrm{Mg}_{0.2} \mathrm{O}_{3-\mathrm{d}}$ and $\mathrm{La}_{9} \mathrm{Sr}_{1} \mathrm{Si}_{6} \mathrm{O}_{6.5}$ electrolytes, Solid State Ionics 249-250 (2013) 17-25.

[4] M.-B. Choi, B. Singh, E.D. Wachsman, S.-J. Song, Performance of $\mathrm{La}_{0.1} \mathrm{Sr}_{0.9} \mathrm{Co}_{0.8} \mathrm{Fe}_{0.2} \mathrm{O}_{3-\delta}$ and $\mathrm{La}_{0.1} \mathrm{Sr}_{0.9} \mathrm{Co}_{0.8} \mathrm{Fe}_{0.2} \mathrm{O}_{3-\delta}-\mathrm{Ce}_{0.9} \mathrm{Gdd}_{0.1} \mathrm{O}_{2}$ oxygen electrodes with $\mathrm{Ce}_{0.9} \mathrm{Gd}_{0.1} \mathrm{O}_{2}$ barrier layer in reversible solid oxide fuel cells, J. Power Sources 239 (2013) 361-373.

[5] M. Žunić, G. Branković, F. Basoli, M. Cilense, E. Longo, J.A. Varela, Stability, characterization and functionality of proton conducting $\mathrm{NiO}-\mathrm{BaCe}_{0.85-\mathrm{x}} \mathrm{Nb}_{\mathrm{x}} \mathrm{Y}_{0.1} 5 \mathrm{O}_{3-\delta}$ cermet anodes for ITSOFC application, J. All. \& Compnds 609 (2014) 7-13.

[6] S. Engels, T. Markus, M. Modigell, L. Singheiser, Oxygen permeation and stability investigations on MIEC membrane materials under operating conditions for power plant process, J. Membrane Sci. 370 (2011) 58-69.

[7] J. Yi, T.E. Weirich, M. Schroeder, $\mathrm{CO}_{2}$ corrosion and recovery of perovskite-type $\mathrm{BaCo}_{1-\mathrm{x}-\mathrm{y}} \mathrm{Fe}_{\mathrm{x}} \mathrm{NbyO}_{3-\delta}$ membranes, J. Membrane Sci. 437 (2013) 49-56.

[8] X. Tan, N. Liu, B. Meng, J. Sunarso, K. Zhang, S. Liu, Oxygen permeation behavior of $\mathrm{La}_{0.6} \mathrm{Sr}_{0.4} \mathrm{Co}_{0.8} \mathrm{Fe}_{0.2} \mathrm{O}_{3}$ hollow fibre membranes with highly concentrated $\mathrm{CO}_{2}$ exposure, $\mathrm{J}$. Membrane Sci. 389 (2012) 216-222. 
[9] T. Ishihara, Perovskite Oxide for Solid Oxide Fuel Cells, 2009.

[10] L. Qiu, T. Ichikawa, A. Hirano, N. Imanishi, Y. Takeda, $\mathrm{Ln}_{1-x} \mathrm{Sr}_{\mathrm{x}} \mathrm{Co}_{1-y} \mathrm{Fe}_{\mathrm{y}} \mathrm{O}_{3-\delta}$ (Ln=Pr, Nd, Gd; $x=0.2,0.3)$ for the electrodes of solid oxide fuel cells, Solid State Ionics 158 (2003) 55-65.

[11] G.C. Kostogloudis, C. Ftikos, Properties of A-site-deficient $\mathrm{La}_{0.6} \mathrm{Sr}_{0.4} \mathrm{Co}_{0.2} \mathrm{Fe}_{0.8} \mathrm{O}_{3-\delta}$-based perovskite oxides, Solid State Ionics 126 (1999) 143-151.

[12] S. Carter, A. Selcuk, R.J. Chater, J. Kajda, J.A. Kilner, B.C.H. Steele, Oxygen transport in selected nonstoichiometric perovskite-struture oxides, Solid State Ionics 53-56, Part 1 (1992) 597605.

[13] P. Batocchi, F. Mauvy, S. Fourcade, M. Parco, Electrical and electrochemical properties of architectured electrodes based on perovskite and $\mathrm{A}_{2} \mathrm{MO}_{4}$-type oxides for Protonic Ceramic Fuel Cell, Electrochimica Acta 145 (2014) 1-10.

[14] J. Dailly, S. Fourcade, A. Largeteau, F. Mauvy, J.C. Grenier, M. Marrony, Perovskite and $\mathrm{A}_{2} \mathrm{MO}_{4}{ }^{-}$ type oxides as new cathode materials for protonic solid oxide fuel cells, Electrochimica Acta 55 (2010) 5847-5853.

[15] H.L. Lein, K. Wiik, T. Grande, Thermal and chemical expansion of mixed conducting $\mathrm{La}_{0.5} \mathrm{Sr}_{0.5} \mathrm{Fe}_{1-\mathrm{x}} \mathrm{Co}_{\mathrm{x}} \mathrm{O}_{3-\delta}$ materials, Solid State Ionics 177 (2006) 1795-1798.

[16] S.-i. Hashimoto, Y. Fukuda, M. Kuhn, K. Sato, K. Yashiro, J. Mizusaki, Oxygen nonstoichiometry and thermo-chemical stability of $\mathrm{La}_{0.6} \mathrm{Sr}_{0.4} \mathrm{Co}_{1-\mathrm{y}} \mathrm{Fe}_{\mathrm{y}} \mathrm{O}_{3-\delta}(\mathrm{y}=0.2,0.4,0.6,0.8)$, Solid State Ionics 181 (2010) 1713-1719.

[17] F. Prado, N. Grunbaum, A. Caneiro, A. Manthiram, Effect of $\mathrm{La}^{3+}$ doping on the perovskite-tobrownmillerite transformation in $\mathrm{Sr}_{1-\mathrm{x}} \mathrm{La}_{\mathrm{x}} \mathrm{Co}_{0.8} \mathrm{Fe}_{0.2} \mathrm{O}_{3-\delta}(0 \leq \mathrm{x} \leq 0.4)$, Solid State Ionics 167 (2004) 147-154.

[18] E. Siebert, A. Boréave, F. Gaillard, T. Pagnier, Electrochemical and Raman study of $\mathrm{La}_{0.7} \mathrm{Sr}_{0.3} \mathrm{Co}_{0.8} \mathrm{Fe}_{0.2} \mathrm{O}_{3-8}$ reduction, Solid State Ionics $247-248$ (2013) 30-40. 
[19] N. Grunbaum, L. Dessemond, J. Fouletier, F. Prado, A. Caneiro, Electrode reaction of $\mathrm{Sr}_{1-\mathrm{x}} \mathrm{La}_{\mathrm{x}} \mathrm{Co}_{0.8} \mathrm{Fe}_{0.2} \mathrm{O}_{3-\delta}$ with $\mathrm{x}=00.1$ and 0.6 on $\mathrm{Ce}_{0.9} \mathrm{Gd}_{0.1} \mathrm{O}_{1.95}$ at $600 \leq \mathrm{T} \leq 800{ }^{\circ} \mathrm{C}$, Solid State Ionics 177 (2006) 907-913.

[20] A. Slodczyk, O. Zaafrani, M.D. Sharp, J.A. Kilner, B. Dabrowski, O. Lacroix, Ph. Colomban, Testing the Chemical/Structural Stability of Proton Conducting Perovskite Ceramic Membranes by in Situ/ex Situ Autoclave Raman Microscopy, Membranes 3 (2013) 311-30.

[21] S. Upasen, P. Batocchi, F. Mauvy, A. Slodczyk, Ph. Colomban, Protonation and structural/chemical stability of $\mathrm{Ln}_{2} \mathrm{NiO}_{4+\delta}$ ceramics vs. $\mathrm{H}_{2} \mathrm{O} / \mathrm{CO}_{2}$ : high temperature / water pressure ageing tests, J.All. \& Compnds 622 (2015) 1074-1085.

[22] B. Sala, F. Grasset, O. Lacroix, A. Sirat, K. Rahmouni, M. Keddam, H. Takenouti, D. Goeuriot, B. Bendjeriou, Ph. Colomban, Method for the optimization of the conductivity of a ion conducting membrane, AREVA, CNRS, ARMINES, SCT; Patent WO 2008/152317 A2 (18-122008).

[23] . B. Sala, F. Grasset, O. Lacroix, A. Sirat, K Rhamouni, M. Keddam, H. Takenouti, D. Goeuriot, B. Bendjeriou, Ph. Colomban, A. Slodczyk, G. Pourcelly, A. Van der Lee, J.G. Sanchez, AREVA, CNRS, ARMINES , Patent EP 12773302.0-1360 (11-10-2012)

[24] L.A. Chick, O.A. Marina, C.A. Coyle, E.C. Effects of temperature and pressure on the performance of a solid oxide fuel cell running on steam reformate of kerosene Thomsen, J. Power Sources 236 (2013) 341-349.

[25] L. Magistri, A. Traverso, F. Cerutti, M. Bozzolo, P. Costamagna, A.F. Massardo, Modelling of Pressurised Hybrid Systems Based on Integrated Planar Solid Oxide Fuel Cella(IP-SOFC) Technology, Fuel Cells 5 (2005) 80-96.

[26] W.J. Yang, S.K. Park, T.S. Kim, J.H. Kim, J.L. Sohn, S.T. Ro, Design performance analysis of pressurized solid oxide fuel cell/gas turbine hybrid systems considering temperature constraints, J. Power Sources 160 (2006) 462-473. 
[27] W. Burbank Jr, D.D. Witmer, F. Holcomb, Model of a novel pressurized solid oxide fuel cell gas turbine hybrid engine, J. Power Sources 193 (2009) 656-664.

[28] Ph. Colomban. Aneta Slodczyk, Oumaya Zaafrani, Olivier Lacroix, Johan Loricourt, Frederic Grasset and Beatrice Sala, What is the True Nature of Conducting Proton in Perovskite Ceramic Membrane: Hydroxyl Ion or Interstitial Proton?, MRS proceeding 1309 (2011) /mrsf10-1309ee03-21 http://dx.doi.org/10.1557/opl.2011.616

[29] Ph. Colomban, A. Slodczyk, D. Lamago, G. Andre, O. Zaafrani, O. Lacroix, S. Willemin, B. Sala, Proton Dynamics and Structural Modifications in the Protonic Conductor Perovskites, j. Phys. Soc. Jpn 79 (2010) Suppl.A 1-6.

[30] Ph. Colomban, C. Tran, O. Zaafrani, A. Slodczyk, Aqua oxyhydroxycarbonate second phases at the surface of $\mathrm{Ba} / \mathrm{Sr}$-based proton conducting perovskites: a source of confusion in the understanding of proton conduction, J. Raman Spectrosc. 44 (2013) 312-320.

[31] A. Slodczyk, Ph. Colomban, S. Willemin, O. Lacroix, B. Sala, Indirect Raman identification of the proton insertion in the high-temperature $[\mathrm{Ba} / \mathrm{Sr}][\mathrm{Zr} / \mathrm{Ti}] \mathrm{O}-3$-modified perovskite protonic conductors, J. Raman Spectrosc. 40 (2009) 513-521.

[32] A. Slodczyk, M. Limage, Ph. Colomban, O. Zaafrani, F. Grasset, J. Loricourt, B. Sala, Substitution and proton doping effect on $\mathrm{SrZrO}_{3}$ behaviour: high-pressure Raman study, J. Raman Spectrosc. 42 (2011) 2089-2099.

[33] A. Slodczyk, Ph. Colomban, D. Lamago, G. Andre, O. Zaafrani, O. Lacroix, A. Sirat, F. Grasset, B. Sala, Optimum temperature range for the proton dynamics in $\mathrm{H}$-doped $\mathrm{BaZrO}_{3}: \mathrm{Yb}$ dense ceramics-a neutron scattering study, J. Mater.Res. 27 (2012) 1939-1949.

[34] A. Slodczyk, Ph. Colomban, G. Andre, O. Zaafrani, F. Grasset, O. Lacroix, B. Sala, Structural modifications induced by free protons in proton conducting perovskite zirconate membrane, Solid State Ionics 225 (2012) 214-218. 
[35] A. Slodczyk, Ph. Colomban, N. Malikova, O. Zaafrani, S. Longeville, J.-M. Zanotti, O. Lacroix, B. Sala, Bulk protons in anhydrous perovskites-neutron scattering studies, Solid State Ionics $252(2013) 7-11$.

[36] S. Upasen, P. Batocchi, A. Slodczyk, Ph. Colomban, F. Mauvy, structural stability of $\mathrm{Ln}_{2} \mathrm{NiO}_{4+\mathrm{d}}$ under high temperature and high water pressure operating conditions, International Discussion on Hydrogen Energy and Applications, Nantes, France, 2014.

[37] L.W. Tai, M.M. Nasrallah, H.U. Anderson, D.M. Sparlin, S.R. Sehlin, Structure and electrical properties of $\mathrm{La}_{1-\mathrm{x}} \mathrm{Sr}_{\mathrm{x}} \mathrm{Co}_{1-\mathrm{y}} \mathrm{FeyO}_{3}$. Part 2. The system $\mathrm{La}_{1-\mathrm{x}} \mathrm{Sr}_{\mathrm{x}} \mathrm{Co}_{0.2} \mathrm{Fe}_{0.8} \mathrm{O}_{3}$, Solid State Ionics 76 (1995) 273-283.

[38] C.C. Wang, T. Becker, K. Chen, L. Zhao, B. Wei, S.P. Jiang, Effect of temperature on the chromium deposition and poisoning of $\mathrm{La}_{0.6} \mathrm{Sr}_{0.4} \mathrm{Co}_{0.2} \mathrm{Fe}_{0.8} \mathrm{O}_{3-\delta}$ cathodes of solid oxide fuel cells, Electrochimica Acta 139 (2014) 173-179.

[39] M. Liu, D. Ding, K. Blinn, X. Li, L. Nie, M. Liu, Enhanced performance of LSCF cathode through surface modification, International J. Hydrogen Energy 37 (2012) 8613-8620.

[40] S. Rousseau, S. Loridant, P. Delichere, A. Boreave, J.P. Deloume, P. Vernoux, $\mathrm{La}_{1-\mathrm{x}} \mathrm{Sr}_{\mathrm{x}} \mathrm{Co}_{1-\mathrm{y}} \mathrm{Fe}_{\mathrm{y}} \mathrm{O}_{3}$ perovskites prepared by sol-gel method : Characterization and relationships with catalytic properties for total oxidation of toluene, Applied Catalysis B: Environmental 88 (2009) 438447.

[41] W. Araki, T. Yamaguchi, Y. Arai, J. Malzbender, Strontium surface segregation in $\mathrm{La}_{0.58} \mathrm{Sr}_{0.4} \mathrm{Co}_{0.2} \mathrm{Fe}_{0.8} \mathrm{O}_{3-\delta}$ annealed under compression, Solid State Ionics 268, Part A (2014) 16.

[42] J.-W. Lee, Z. Liu, L. Yang, H. Abernathy, S.-H. Choi, H.-E. Kim, M. Liu, Preparation of dense and uniform $\mathrm{La}_{0.6} \mathrm{Sr}_{0.4} \mathrm{Co}_{0.2} \mathrm{Fe}_{0.8} \mathrm{O}_{3-\delta}$ (LSCF) films for fundamental studies of SOFC cathodes, J. Power Sources 190 (2009) 307-310. 
[43] A. Slodczyk, M.D. Sharp, S. Upasen, Ph. Colomban, J.A. Kilner, Combined bulk and surface analysis of the $\mathrm{BaCe}_{0.5} \mathrm{Zr}_{0.3} \mathrm{Y}_{0.16} \mathrm{Zn}_{0.04} \mathrm{O}_{3-\delta}$ (BCZYZ) ceramic proton-conducting electrolyte, Solid State Ionics 262 (2014) 870-874.

[44] C. Burlet, Y. Vanbrabant, H. Goethals, T. Thys, L. Dupin, Raman spectroscopy as a tool to characterize heterogenite ( $\mathrm{CoO} \cdot \mathrm{OH})$ (Katanga Province, Democratic Republic of Congo), Spectrochimica Acta Part A: Molecular and Biomolecular Spectroscopy 80 (2011) 138-147.

[45] G. Gouadec, Ph. Colomban, Raman Spectroscopy of nanomaterials: How spectra relate to disorder, particle size and mechanical properties, Progr. Cryst. Growth \& Charact. Mater 53 (2007) 1-56.

[46] C.-W. Tang, C.-B. Wang, S.-H. Chien, Characterization of cobalt oxides studied by FT-IR, Raman, TPR and TG-MS, Thermochimica Acta 473 (2008) 68-73.

[47] E. Boehm, J.M. Bassat, M.C. Steil, P. Dordor, F. Mauvy, J.C. Grenier, Oxygen transport properties of $\mathrm{La}_{2} \mathrm{Ni}_{1-x} \mathrm{Cu}_{x} \mathrm{O}_{4+\delta}$ mixed conducting oxides, Solid State Sci. 5 (2003) 973-981.

[48] M.A. Legodi, D. de Waal, The preparation of magnetite, goethite, hematite and maghemite of pigment quality from mill scale iron waste, Dyes and Pigments 74 (2007) 161-168.

[49] A. Orera, G. Larraz, M. Sanjuan, Spectroscopic study of the competition between dehydration and carbonation effects in $\mathrm{La}_{2} \mathrm{O}_{3}$-based materials, J. Eur. Cer. Soc. 33 (2013) 2103-2110.

[50] W. Kaabar, S. Bott, R. Devonshire, Raman spectroscopic study of mixed carbonate materials, Spectrochimica Acta Part A: Molecular and Biomolecular Spectroscopy 78 (2011) 136-141.

[51] D. De Waal, K.J. Range, M. Konigstein, W. Kiefer, Raman spectra of the barium oxide peroxide and strontium oxide peroxide series, J. Raman Spectrosc. 29 (1998) 109-113.

[52] H. Samata, D. Kimura, S. Mizusaki, Y. Nagata, T.C. Ozawa, A. Sato, Syntesis and characterization of neodymium oxyhydroxide crystals, J. All. \&Compnds 468 (2009) 566570. 
[53] Q. Jiao, M. Fu, C. You, Y. Zhao, H. Li, Preparation of Hollow $\mathrm{Co}_{3} \mathrm{O}_{4}$ Microspheres and Their Ethanol Sensing Properties, Inorganic Chemistry 51 (2012) 11513-11520.

[54] J. Yang, H. Cheng, R.L. Frost, Synthesis and characterisation of cobalt hydroxy carbonate $\mathrm{Co}_{2} \mathrm{CO}_{3}(\mathrm{OH})_{2}$ nanomaterials, Spectrochimica Acta Part A: Molecular and Biomolecular Spectroscopy 78 (2011) 420-428.

[55] A.I. Cuza, The Raman study of certain carbonates, Anal Şt Univ Al I Cuza Iaşi Geologie 2 (2009) 97-112.

[56] F. Froment, A. Tournie, Ph. Colomban, Raman identification of natural red to yellow pigments : ochre and iron-containing ores, J.Raman Spectrosc. 39 (2008) 560-568.

[57] Application Note AN\#79: Attenuated Total Reflection (ATR) - a versatile tool for FT-IR spectroscopy. Bruker Optics Inc., (2011) [cited 201523 january 2015]; Available from: http://www.bruker.com/fileadmin/user upload/8-PDF-Docs/OpticalSpectrospcopy/FT$\underline{\text { IR/ALPHA/AN/AN79 ATR-Basics EN.pdf. }}$

[58] K. Ohta, R. Iwamoto, Experimental Proof of the Relation Between Thickness of the Probed Surface Layer and Absorbance in FT-IR/ATR Spectroscopy, Applied Spectroscopy 39 (1985) 418-425.

[59] M.A. Alavi, A. Morsali, Syntheses and characterization of $\mathrm{Sr}(\mathrm{OH})_{2}$ and $\mathrm{SrCO}_{3}$ nanostructures by ultrasonic method, Ultrasonics Sonochemistry 17 (2010) 132-138.

[60] P. Ptáček, E. Bartoníčková, J. Švec, T. Opravil, F. Šoukal, F. Frajkorová, The kinetics and mechanism of thermal decomposition of $\mathrm{SrCO}_{3}$ polymorphs, Ceramics International 41 (2015) 115-126. 


\section{Figure Captions}

Figure 1: Comparison of X-ray patterns a) as-prepared vs. protonated LSCF6428 under 20 bar $\mathrm{CO}_{2}$-free water b) as-prepared vs. protonated LSCF6428 under 40 bar $\mathrm{CO}_{2}$ free water.

Figure 2: a) Raman spectra (458 $\mathrm{nm}$ ) of as-prepared LSCF6428 ceramic as a function of laser power b) Oxidation relative intensity peak $\left(\mathrm{I}_{569} / \mathrm{I}_{662}\right)$ versus laser power.

Figure 3: Raman signatures of as-prepared LSCF6428 ceramic at different surface area/laser power/wavelengths and of $\mathrm{Co}_{3} \mathrm{O}_{4}$ obtained by thermal treatment of CoO.OH [44]. (* corresponds to $\mathrm{Co}_{3} \mathrm{O}_{4}$ traces).

Figure 4: mass uptake evolution of LSCF6428 ceramic pellet during 47 days of protonation treatment $\left(20\right.$ bar of $\mathrm{CO}_{2}$-free water and $\left.550^{\circ} \mathrm{C}\right)$.

Figure 5: Micro features $(10 \mu \mathrm{m})$ of LSCF6428's surface sample in different states (a) asprepare sample (b) 40 bar of $\mathrm{CO}_{2}$-free water pressure for 8 days (c) 20 bar of $\mathrm{CO}_{2-}$ free water pressure for 47 days (d) 40 bar of $\mathrm{CO}_{2}$-saturated water pressure for 8 days.

Figure 6: a) Thermal analysis of as-prepared and protonated LSCF6428 b) corresponding TG weight loss difference, $\% w t_{p}-\% w t_{n p}$ c) Two consecutive thermal expansion (length variation/initial length) curves of as-prepared and protonated LSCF6428 under free- $\mathrm{CO}_{2}$ water pressure.

Figure 7: Raman spectra of LSCF6428 ceramic in different states, protonated and deprotonated, recorded a) on surface b) in bulk. (Note: the used symbols are described in Table 2 and sample labels are indicated in the Text) 
Figure 8: ATR and micro ATR-FTIR spectra recorded at the surface of as-prepared (a, b), protonated under 20 bar free- $\mathrm{CO}_{2}(\mathrm{c})$, under 40 bar free- $\mathrm{CO}_{2}(\mathrm{~d}), 40$ bar absorbed$\mathrm{CO}_{2}(\mathrm{e})$ and thermal treatment (f). (Note: ${ }^{*}$ indicates the spectra collected with the $\mu$-ATR Ge crystal)

Figure 9: Raman mapping along the fresh cross-section fracture of LSCF6428 ceramic pellets protonated under a) 20 bar of $\mathrm{CO}_{2}$-free water b) 40 bar of $\mathrm{CO}_{2}$-free water c) 40 bar of $\mathrm{CO}_{2}$ saturated water.

Figure 10: Comparison of corrosion rate ( $\mu \mathrm{m} /$ day) of various Electrolytes [20] and Electrodes treated in Autoclave under different conditions (see text for label). 

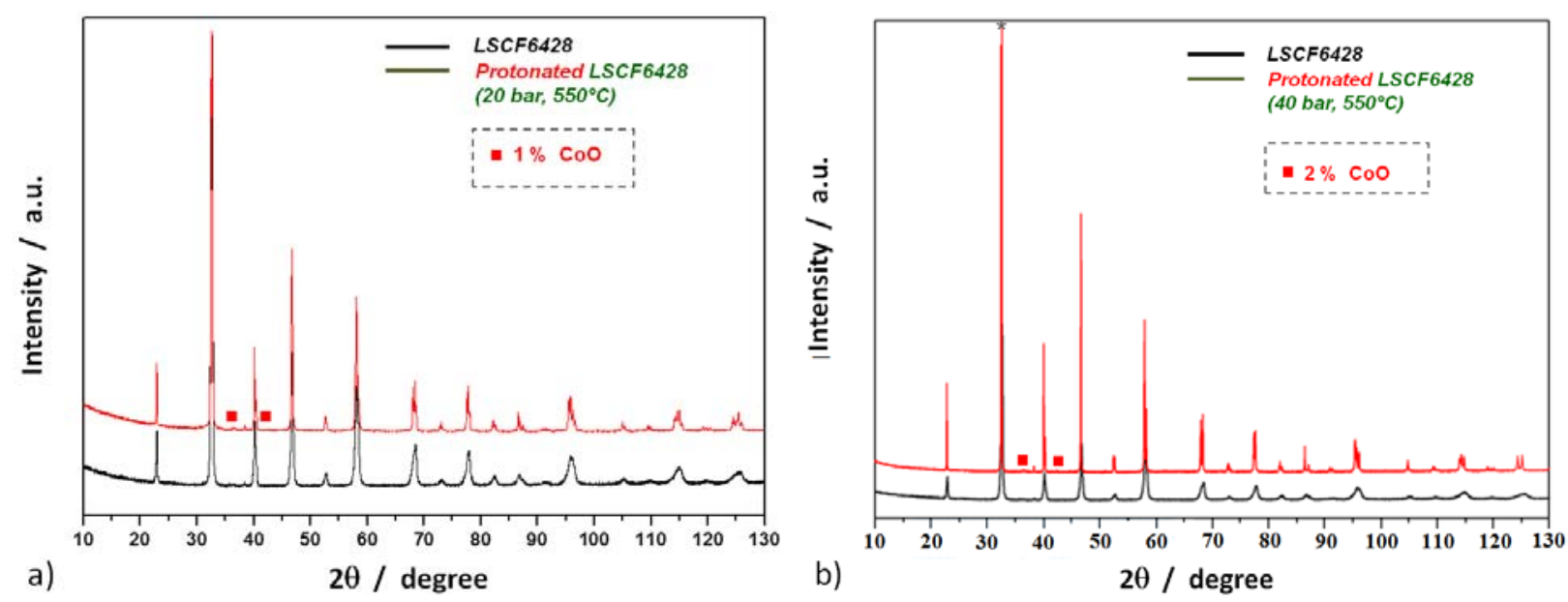

Figure 1: Comparison of X-ray patterns a) as-prepared vs. protonated LSCF6428 under 20 bar $\mathrm{CO}_{2}$-free water b) as-prepared vs. protonated $\mathrm{LSCF} 628$ under 40 bar $\mathrm{CO}_{2}$-free water.

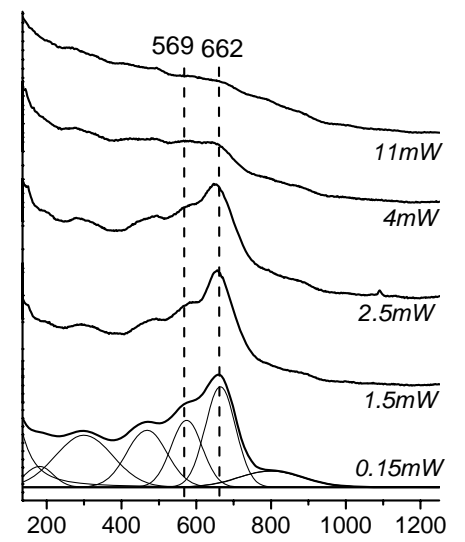

a)
Wavenumber $/ \mathrm{cm}^{-1}$

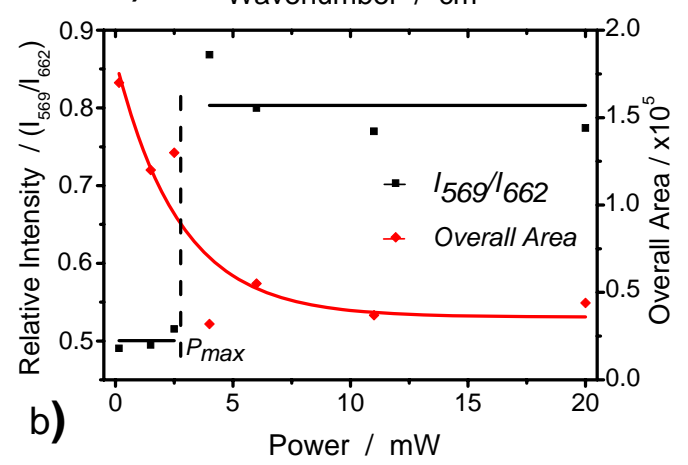

Figure 2: a) Raman spectra (458 $\mathrm{nm}$ ) of as-prepared LSCF6428 ceramic as a function of laser power b) Oxidation relative intensity peak $\left(I_{569} / I_{662}\right)$ versus laser power. 


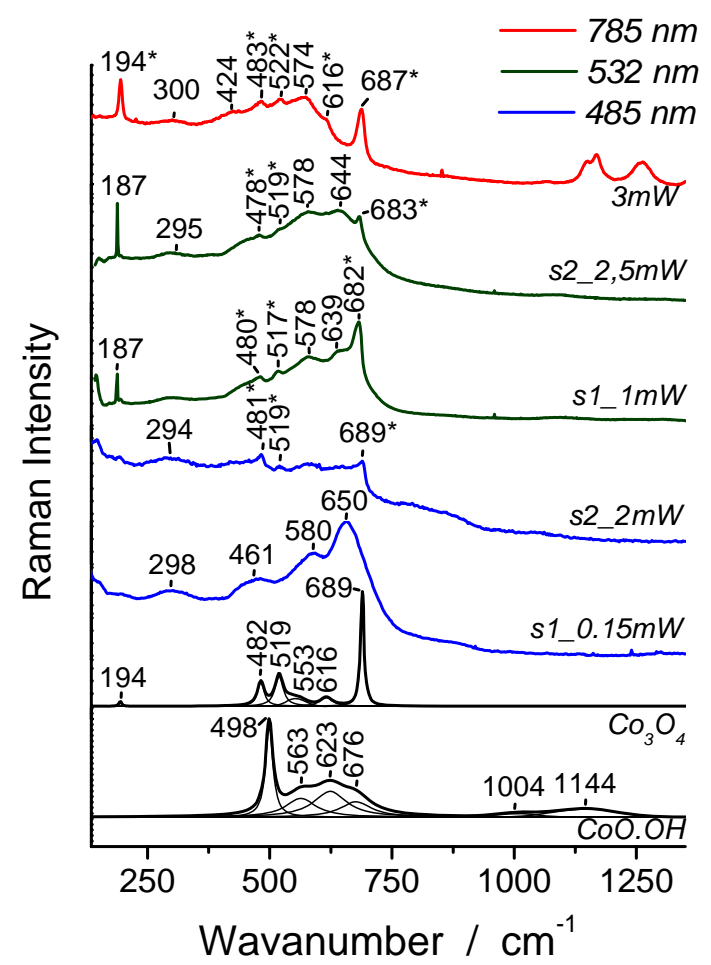

Figure 3: Raman signatures of as-prepared LSCF6428 ceramic at different surface area/laser power/wavelengths and of $\mathrm{Co}_{3} \mathrm{O}_{4}$ obtained by thermal treatment of $\mathrm{CoO} . \mathrm{OH}$ [44]. (* corresponds to $\mathrm{Co}_{3} \mathrm{O}_{4}$ traces).

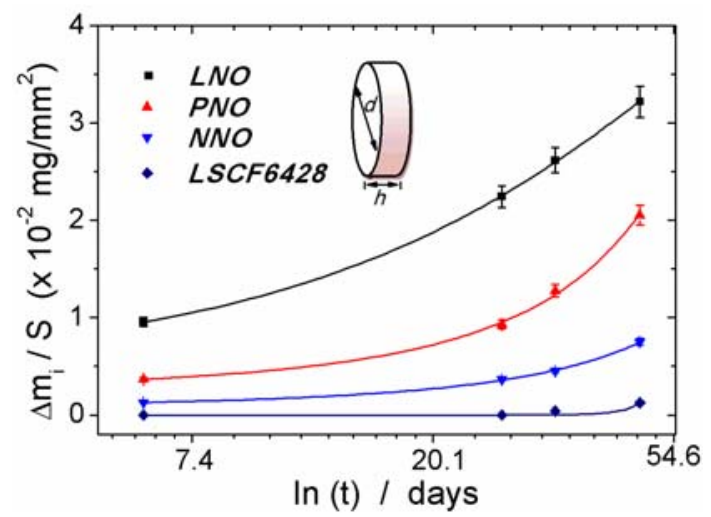

Figure 4: mass uptake evolution of LSCF6428 ceramic pellet during 47 days of protonation treatment (20 bar of $\mathrm{CO}_{2}$-free water and $550^{\circ} \mathrm{C}$ ). 

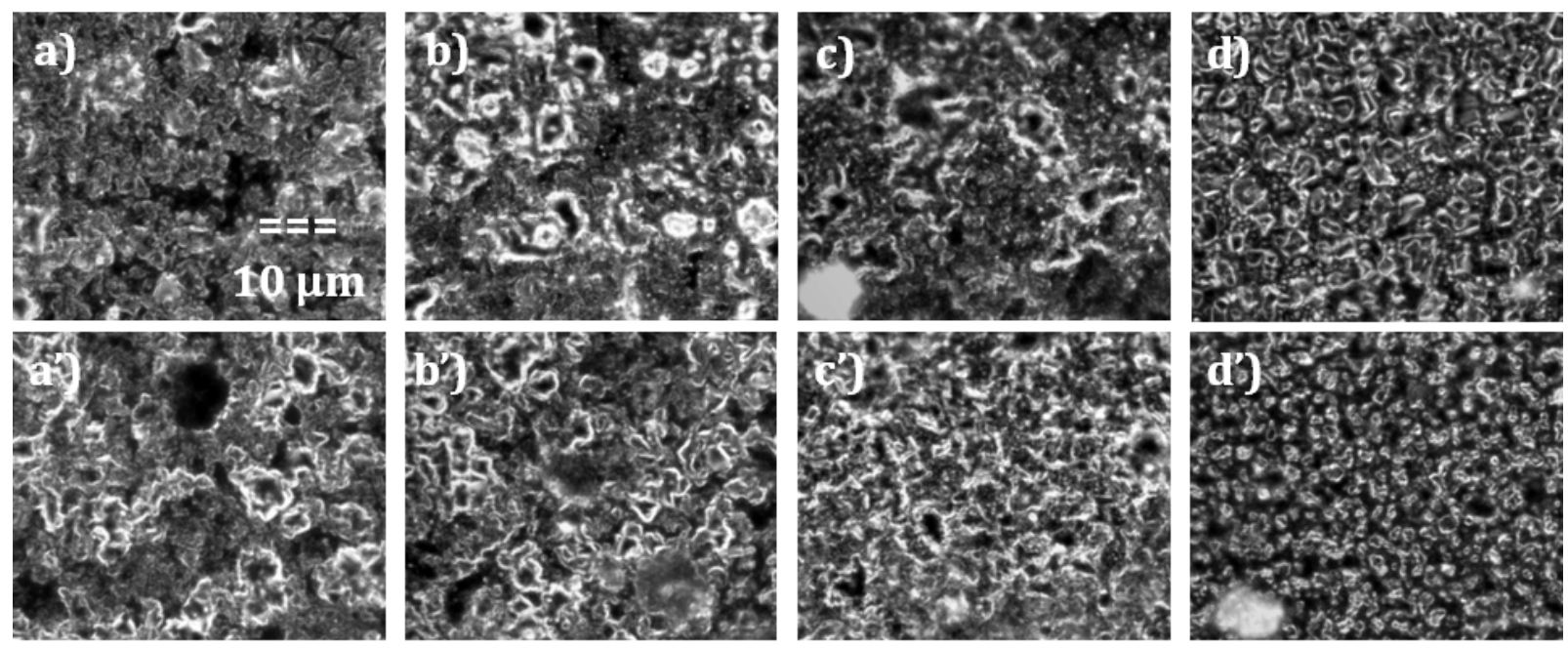

Figure 5: Micro features (10 $\mu \mathrm{m})$ of LSCF6428's surface sample in different states (a) asprepare sample (b) 40 bar of $\mathrm{CO}_{2}$-free water pressure for 8 days (c) 20 bar of $\mathrm{CO}_{2}$-free water pressure for 47 days (d) 40 bar of $\mathrm{CO}_{2}$-saturated water pressure for 8 days.
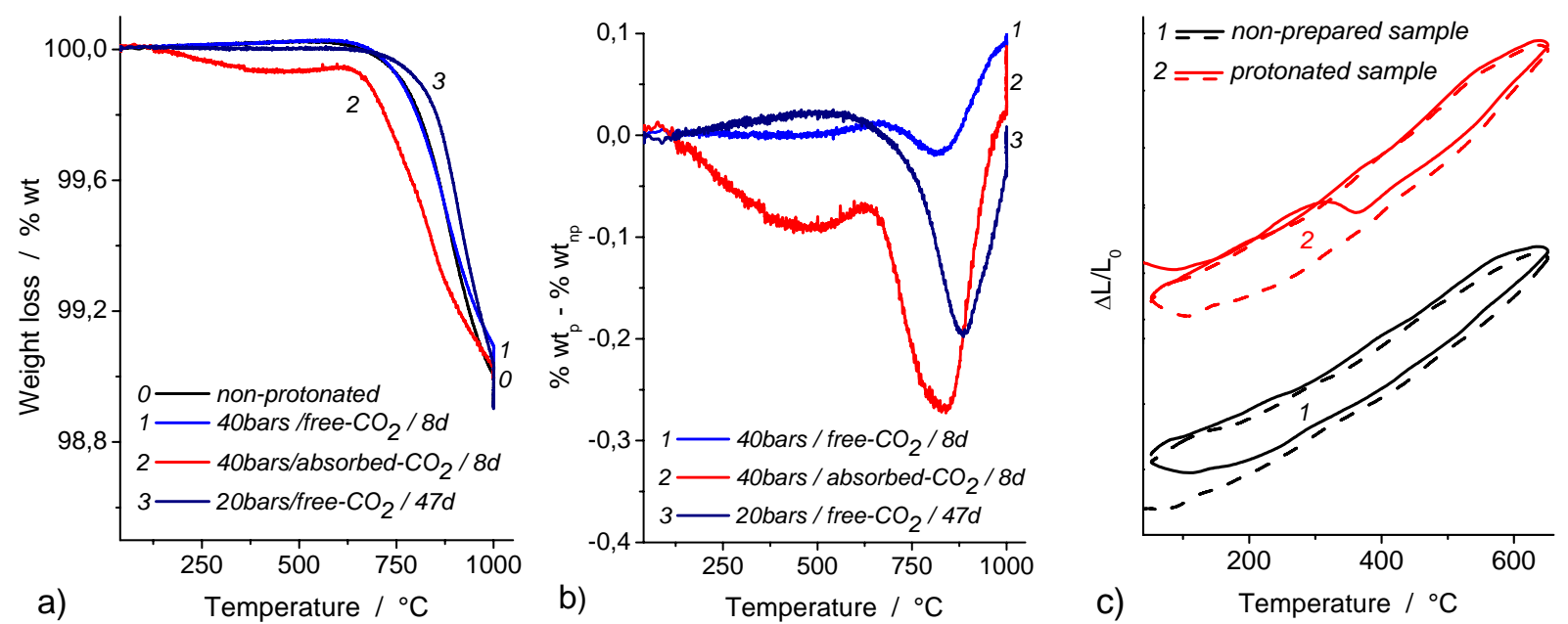

Figure 6: a) Thermal analysis of as-prepared and protonated LSCF6428 b) corresponding TG weight loss difference, \%wt $t_{p} \% w t_{n p}$ c) Two consecutive thermal expansion (length variation/initial length) curves of as-prepared and protonated LSCF6428 under free-CO water pressure. 

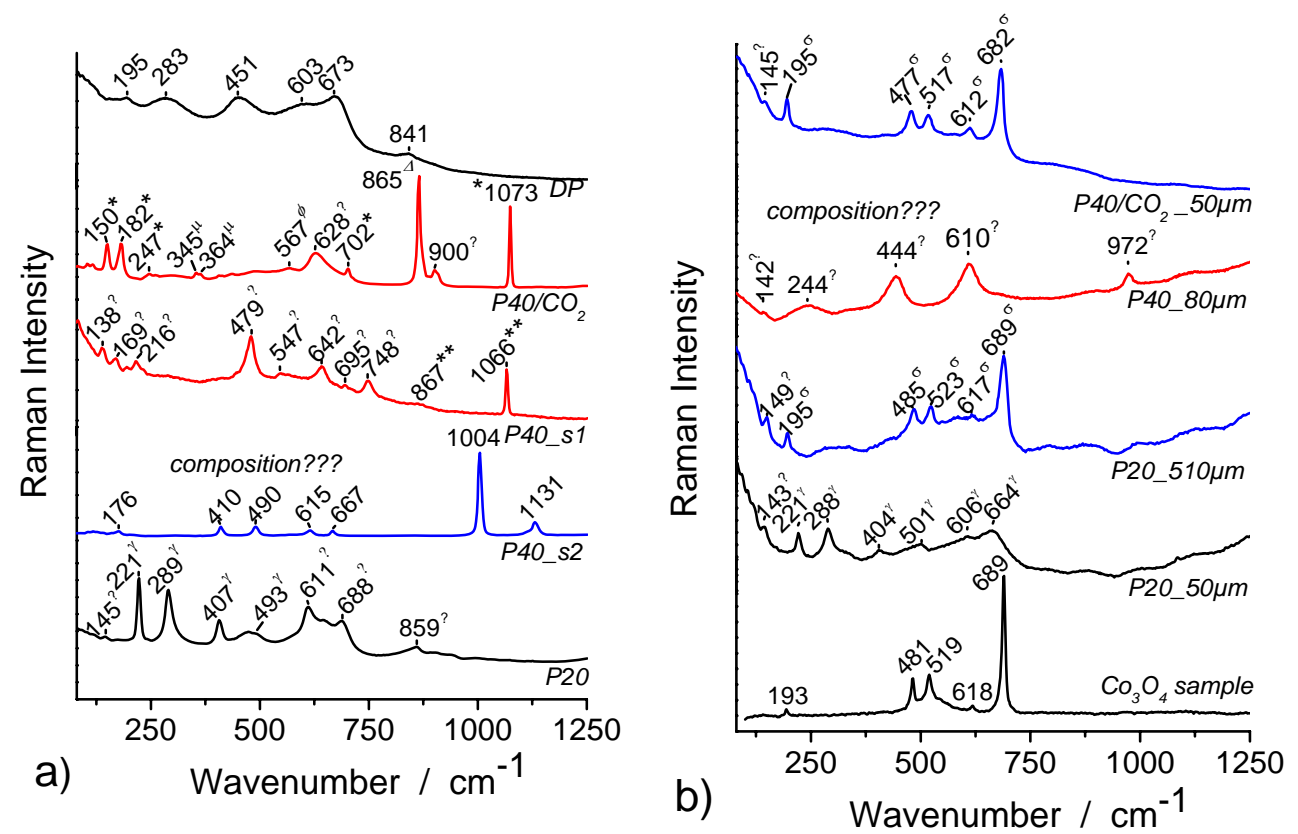

Figure 7: Raman spectra of LSCF6428 ceramic in different states, protonated and deprotonated, recorded a) on surface b) in bulk. (Note: the used symbols are described in Table 2 and sample labels are indicated in the Text) 

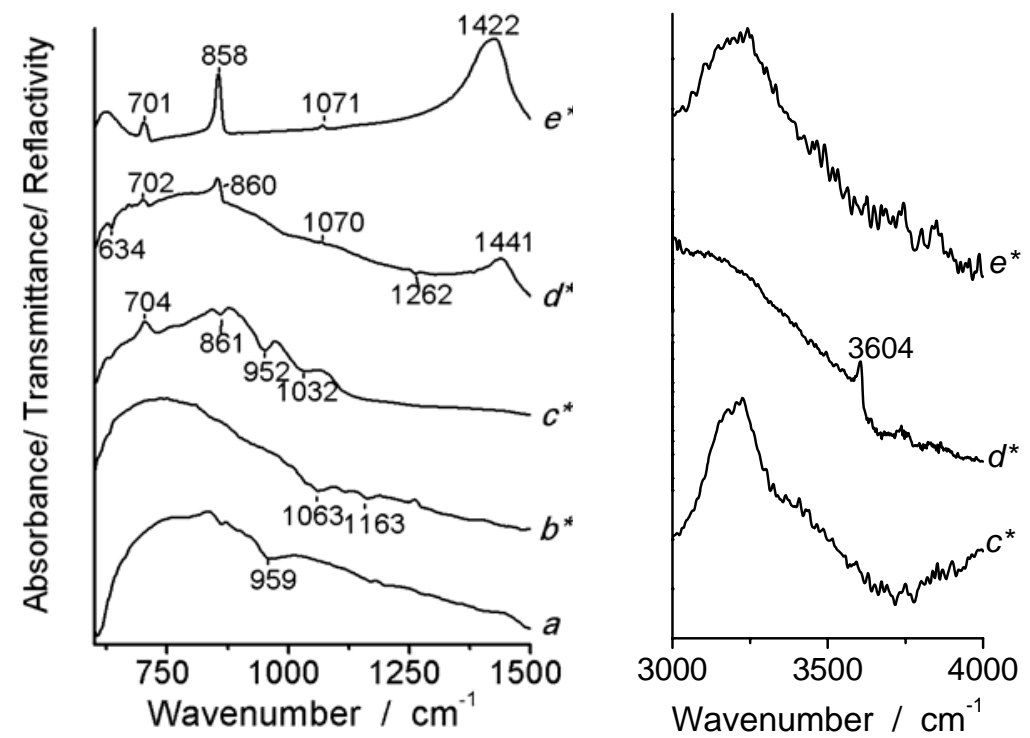

Figure 8: ATR and micro ATR-FTIR spectra recorded at the surface of as-prepared $(a, b)$, protonated under 20 bar free- $\mathrm{CO}_{2}(c)$, under 40 bar free- $\mathrm{CO}_{2}(\mathrm{~d}), 40$ bar absorbed-CO thermal treatment (f). (Note: * indicates the spectra collected with the $\mu$-ATR Ge crystal)
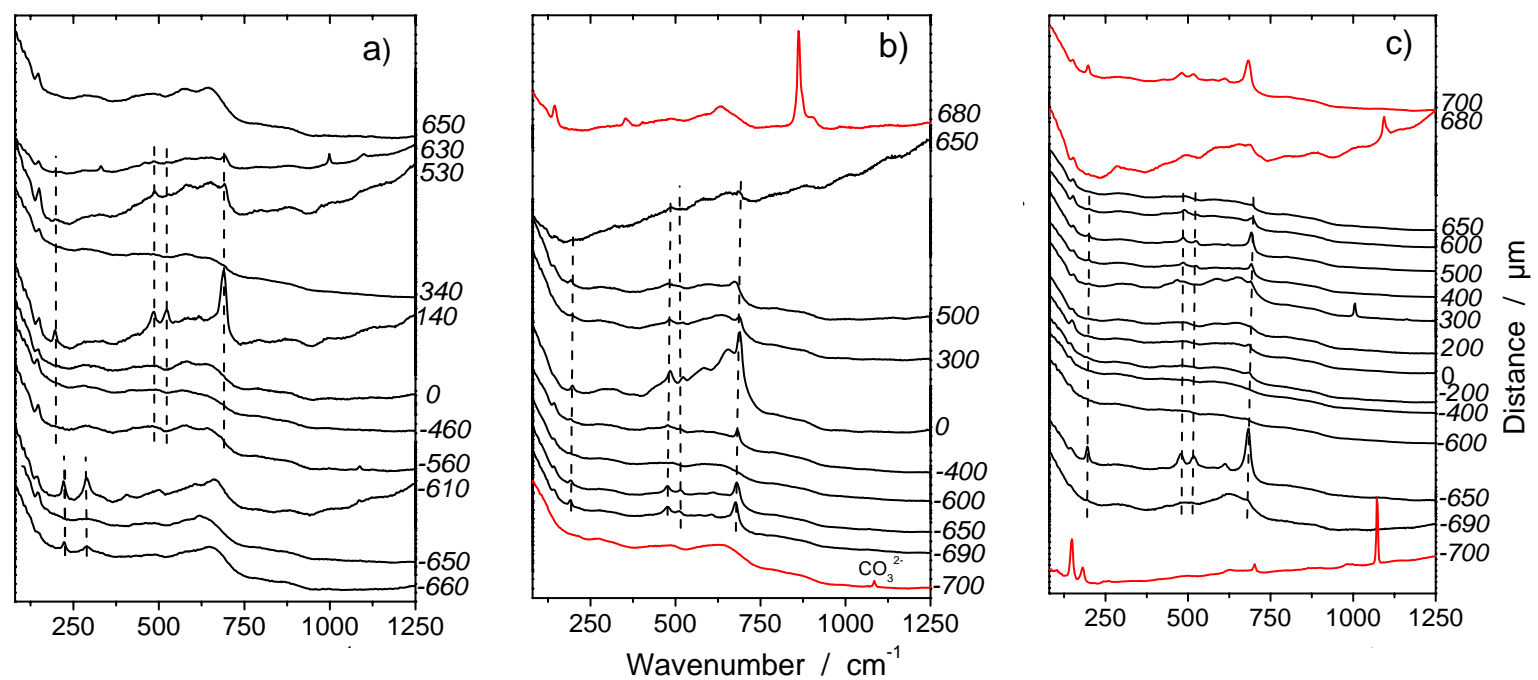

Figure 9: Raman mapping along the fresh cross-section fracture of LSCF6428 ceramic pellets protonated under a) 20 bar of $\mathrm{CO}_{2}$-free water b) 40 bar of $\mathrm{CO}_{2}$-free water c) 40 bar of $\mathrm{CO}_{2}$ saturated water. 

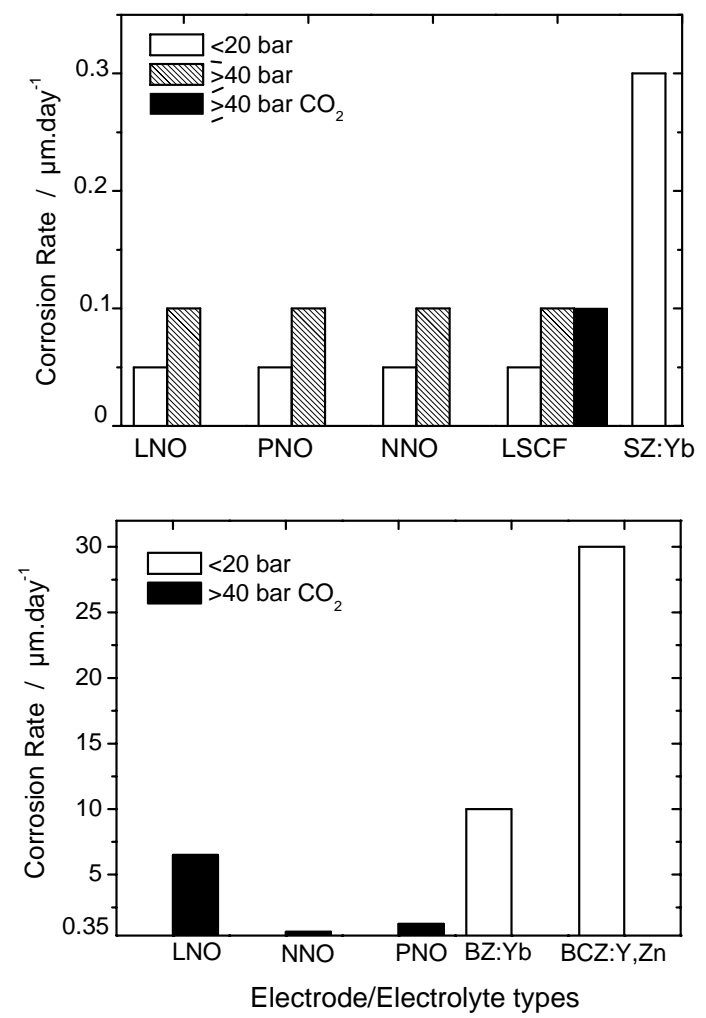

Figure 10: Comparison of corrosion rate ( $\mu \mathrm{m} /$ day) of various Electrolytes [20] and Electrodes treated in Autoclave under different conditions (see text for label). 
Chemical and structural stability of $\mathrm{La}_{0.6} \mathrm{Sr}_{0.4} \mathrm{Co}_{0.2} \mathrm{Fe}_{0.8} \mathrm{O}_{3-\delta}$ ceramic vs. medium/high water vapor pressure

S. Upasen ${ }^{\mathrm{a}, \mathrm{b}}$, P. Batocchic, F. Mauvy ${ }^{\mathrm{c}}$, A. Slodczyk ${ }^{\mathrm{a}, \mathrm{b}}$, Ph. Colombana,b

a Sorbonne Universités, UPMC Univ Paris 06, UMR 8233, MONARIS, 75005, Paris, France

b CNRS, UMR 8233, MONARIS, F-75005, Paris, France

c ICMCB, ICMCB-CNRS-IUT-Université de Bordeaux, 33608 PESSAC Cedex, France 


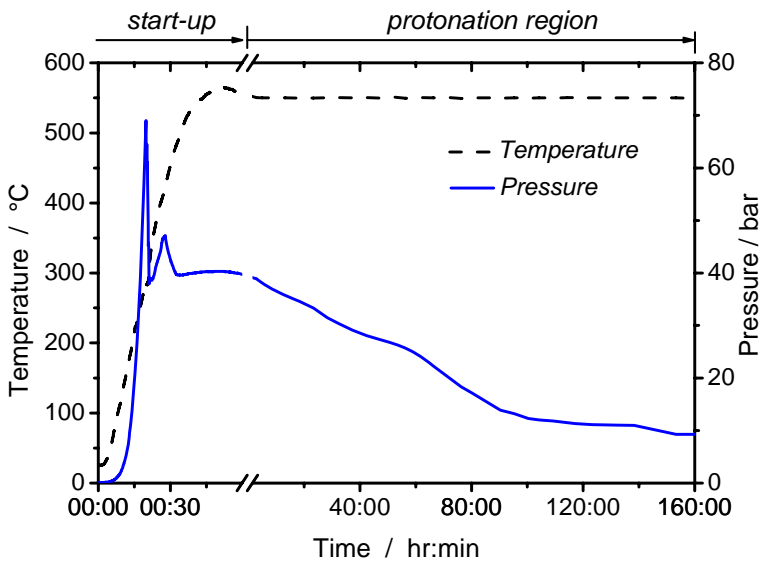

Figure S1 : Example of a plot presenting pressure drop and temperature evolution v.s. protonation time.

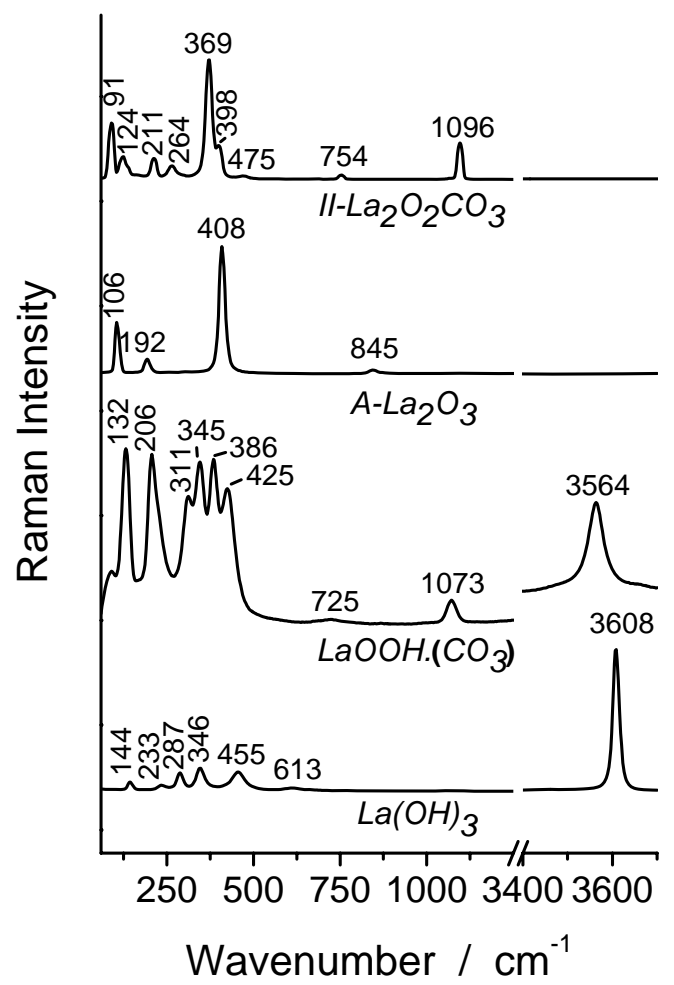

Figure S2: Raman spectra of $\mathrm{La}(\mathrm{OH})_{3}, \mathrm{LaOOH} .\left(\mathrm{CO}_{3}\right)$ and $\mathrm{A}-\mathrm{La}_{2} \mathrm{O}_{3}$ phase obtained by in-situ thermal treatment of hydroscopic $\mathrm{La}_{2} \mathrm{O}_{3}$ powder sample, and a Raman spectrum of II$\mathrm{La}_{2} \mathrm{O}_{2} \mathrm{CO}_{3}$ power sample at room temperature. 
Table S1: Summary of Autoclave Treatment of Electrolyte and Electrode Samples

\begin{tabular}{|c|c|c|c|c|c|}
\hline \multirow{2}{*}{ Sample Types } & \multirow{2}{*}{ pristine state } & \multicolumn{3}{|c|}{ Autoclave Treatment } & \multirow{2}{*}{$\begin{array}{c}\text { Corrosion rate } \\
(\mu \mathrm{m} / \mathrm{day})\end{array}$} \\
\hline & & time & $\mathrm{T} /{ }^{\circ} \mathrm{C}$ & P / bar & \\
\hline & \multicolumn{5}{|c|}{ Electrolyte group [19] } \\
\hline $\begin{array}{l}\mathrm{BaCe}_{0.5} \mathrm{Zr}_{0.3} \mathrm{Y}_{0.16} \mathrm{Zn}_{0.04} \mathrm{O}_{3-} \\
\delta\end{array}$ & $\begin{array}{l}\text { high density }(97 \%) \text {, } \\
\text { ceramic pellet, middle } \\
\text { brown }\end{array}$ & $30 \mathrm{~h}$ & 500 & 10 & $\overline{\sim 30}$ \\
\hline $\mathrm{BaZr}_{0.25} \operatorname{In}_{0.75} \mathrm{O}_{3-\delta}$ & $\begin{array}{l}\text { dense }(90 \%) \text {, ceramic } \\
\text { pellet, light brown }\end{array}$ & $5 \mathrm{~d}$ & 300 & 80 & $>150$ \\
\hline $\mathrm{BaZr}_{0.9} \mathrm{Yb}_{0.1} \mathrm{O}_{3-\delta}$ & $\begin{array}{l}\text { high density }(97 \%) \text {, } \\
\text { ceramic pellet, middle } \\
\text { brown }\end{array}$ & $23 \mathrm{~d}$ & 200 & 15 & $\sim 10$ \\
\hline \multirow[t]{2}{*}{$\mathrm{SrZr}_{0.9} \mathrm{Yb}_{0.1} \mathrm{O}_{3-\delta}$} & \multirow{2}{*}{$\begin{array}{l}\text { high density }(97 \%) \text {, } \\
\text { ceramic pellet, middle } \\
\text { brown }\end{array}$} & $5-23 \mathrm{~d}$ & $\begin{array}{c}200 \\
\text { or }\end{array}$ & 15 & $<0,25$ \\
\hline & & $5 \mathrm{~d}$ & 500 & 80 & \\
\hline \multirow[b]{2}{*}{$\mathrm{La}_{2} \mathrm{NiO}_{4+\delta}$} & \multicolumn{5}{|c|}{ Electrode group [20] } \\
\hline & \multirow[t]{3}{*}{$\begin{array}{l}\text { High density (95\%), } \\
\text { ceramic pellet, black }\end{array}$} & $47 \mathrm{~d}$ & 550 & 20 & $<0.1$ \\
\hline \multirow{5}{*}{$\mathrm{Pr}_{2} \mathrm{NiO}_{4+\delta}$} & & 8 & 550 & 40 & 0.1 \\
\hline & & 8 & 550 & $\begin{array}{c}40 \\
\left(\mathrm{CO}_{2} \text {-sturated }\right) \\
\end{array}$ & $\sim 5$ \\
\hline & \multirow{3}{*}{$\begin{array}{l}\text { High density (95\%), } \\
\text { ceramic pellet, black }\end{array}$} & $47 \mathrm{~d}$ & 550 & 20 & $<0.1$ \\
\hline & & 8 & 550 & 40 & $\sim 0.1$ \\
\hline & & 8 & 550 & $\begin{array}{c}40 \\
\left(\mathrm{CO}_{2} \text {-sturated }\right) \\
\end{array}$ & $\sim 1.25$ \\
\hline \multirow[t]{3}{*}{$\mathrm{Nd}_{2} \mathrm{NiO}_{4+\delta}$} & \multirow{3}{*}{$\begin{array}{l}\text { High density (95\%), } \\
\text { ceramic pellet, black }\end{array}$} & $47 \mathrm{~d}$ & 550 & 20 & $<0.1$ \\
\hline & & 8 & 550 & 40 & $\sim 0.1$ \\
\hline & & 8 & 550 & $\begin{array}{c}40 \\
\left(\mathrm{CO}_{2} \text {-sturated }\right) \\
\end{array}$ & $\sim 0.6$ \\
\hline \multirow[t]{3}{*}{$L a_{0.6} \mathrm{Sr}_{0.4} \mathrm{Co}_{0.2} \mathrm{Fe}_{0.8} \mathrm{O}_{3-\delta}$} & \multirow{3}{*}{$\begin{array}{l}\text { High density (95\%), } \\
\text { ceramic pellet, black }\end{array}$} & $47 \mathrm{~d}$ & 550 & 20 & $<0.01$ \\
\hline & & 8 & 550 & 40 & $\sim 0.1$ \\
\hline & & 8 & 550 & $\begin{array}{c}40 \\
\left(\mathrm{CO}_{2} \text {-sturated }\right)\end{array}$ & $\sim 0.1$ \\
\hline
\end{tabular}

